Mauritius: Public Expenditure and Financial Accountability (PEFA) Assessment 


\title{
Mauritius: Public Expenditure and Financial Accountability (PEFA) Assessment
}

This paper was prepared based on the information available at the time it was completed in August 2011. The views expressed in this document are those of the staff team and do not necessarily reflect the views of the government of Mauritius or the Executive Board of the IMF.

The policy of publication of staff reports and other documents allows for the deletion of market-sensitive information.

\author{
Copies of this report are available to the public from \\ International Monetary Fund • Publication Services \\ $70019^{\text {th }}$ Street, N.W. $\bullet$ Washington, D.C. 20431 \\ Telephone: (202) 623-7430 • Telefax: (202) 623-7201 \\ E-mail: publications@imf.org Internet: http://www.imf.org
}

\section{International Monetary Fund Washington, D.C.}




\section{INTERNATIONAL MONETARY FUND}

Fiscal Affairs Department

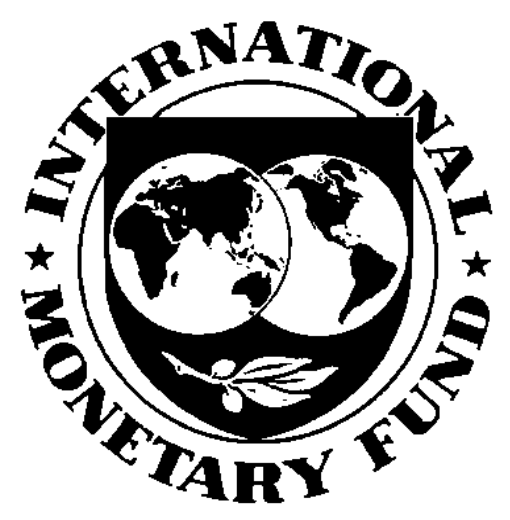

MAURITIUS

\section{Public Expenditure AND FinANCIAL AcCountability (PEFA) Assessment}

Prepared by staff from the Government of Mauritius, the IMF, EU, and the World Bank

\section{August 2011}


The contents of this report constitute technical advice provided by the staff of the International Monetary Fund (IMF) to the authorities of the Mauritius (the "TA recipient") in response to their request for technical assistance. This report (in whole or in part) or summaries thereof may be disclosed by the IMF to IMF Executive Directors and members of their staff, as well as to other agencies or instrumentalities of the TA recipient, and upon their request, to World Bank staff and other technical assistance providers and donors with legitimate interest, unless the TA recipient specifically objects to such disclosure (see Operational Guidelines for the Dissemination of Technical Assistance Information http://www.imf.org/external/np/pp/eng/2009/040609.pdf). Disclosure of this report (in whole or in part) or summaries thereof to parties outside the IMF other than agencies or instrumentalities of the TA recipient, World Bank staff, other technical assistance providers and donors with legitimate interest shall require the explicit consent of the TA recipient and the IMF's Fiscal Affairs Department. 
Preface

Abbreviations.

Executive Summary

I. Introduction

II. Country Background Information .14

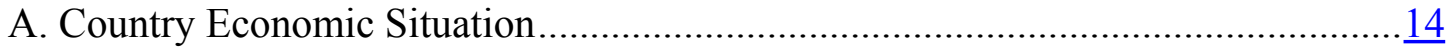

B. Budgetary Outcomes ............................................................................ $\frac{16}{18}$

C. Legal and Institutional Framework ......................................................... 18

III. Assessment of PFM Systems, Processes, and Institutions ........................................ 19

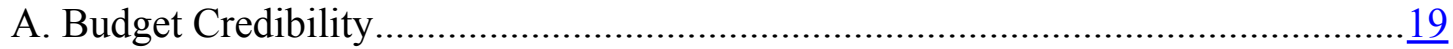

B. Comprehensiveness and Transparency …................................................. $\frac{24}{31}$

C. Policy-based Budgeting .............................................................................. $\frac{31}{33}$

D. Predictability and Control in Budget Execution ................................................ $\underline{33}$

E. Accounting, Recording, and Reporting ........................................................ $\frac{45}{48}$

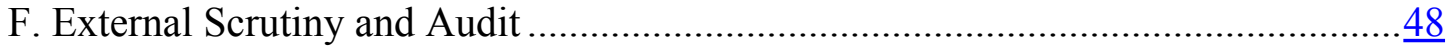

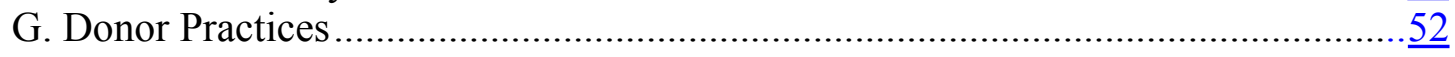

IV. Government Reform Process.......................................................................... 55

Tables

1. Summary of PFM Performance Assessment ............................................................ 10

2. Budgetary Central Government Outturns ........................................................... 16

3. Government Expenditures by Economic Classification ..............................................17

4. Impact of Special Funds on Budget Aggregate Outturn.............................................. 17

5. Central Government Primary Budget and Actual Expenditure ......................................20

6. Comparison of Budget and Actual Capital Expenditure ............................................20

7. Comparison of Budget and Actual Aggregate Capital Expenditure............................... 22

8. Actual Domestic Revenue Compared to Original Budget Estimates ............................. 23

9. Comprehensiveness of Budget Documentation......................................................26

10. Public Access to Fiscal Information ...................................................................... $\underline{30}$

11. Budget Submission Dates ...................................................................................... $\frac{31}{31}$

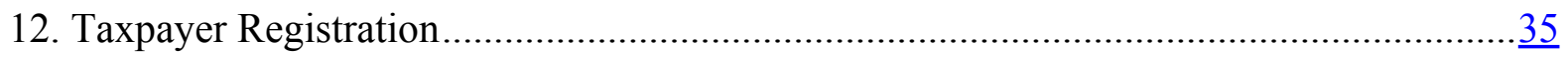

13. Government Financial Accounts Audited...............................................................

14. Total Direct Budget Support Actual versus Estimated ............................................. $\underline{53}$

15. Direct Budget Support Grants: Actual versus Estimates ........................................... $\underline{53}$ 
16. Direct Budget Support Loans: Actual versus Estimates ......................................... 54

17. Aid Managed through National Procedures .......................................................... 55

Annexes

1. Stakeholders Met ............................................................................................. 57

II. Background Documents and Previous Analytical Work References............................. $\underline{60}$

III. Detailed Tables and Calculations ......................................................................

Annex Tables

A1. Material Special Fund Movements in the Assessment Period 2007-08 to 2009 ..............61

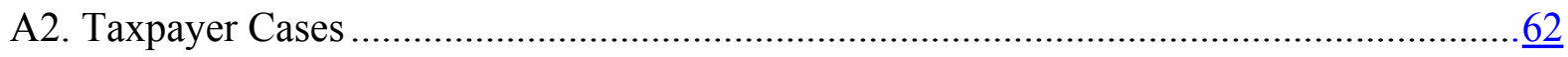

A3. Comparison between Actual and Central Budgetary ............................................... $\underline{63}$

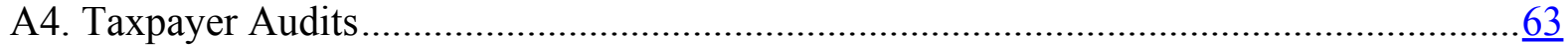

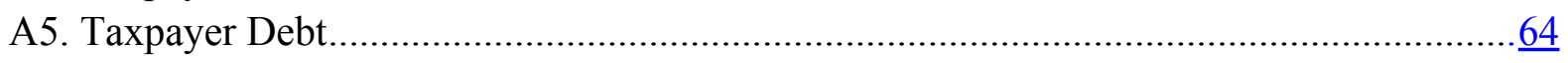




\section{PrefaCe}

In 2010, the Government of Mauritius (GoM) requested the Fiscal Affairs Department (FAD) of the International Monetary Fund (IMF) to assist in carrying out a Public Expenditure and Financial Accountability (PEFA) assessment for Mauritius. The IMF, with support from the World Bank (WB) and the European Union (EU), agreed to assist the government in an external validation of a PEFA self-assessment and a formal agreement was signed in September 2010.

The PEFA methodology provides a framework for governments and other stakeholders to assess key components of the public financial management (PFM) system in a country. The assessment is based on a standardized format developed by a multi-donor group, including the IMF, WB, EU and several bilateral donors. Over 100 countries have carried out, or are in various stages of carrying out, PEFA assessments.

The authorities established a technical team of the Ministry of Finance and Economic Development (MoFED) officials, reporting to Mr. Ali Mansoor, Financial Secretary, and led by Mr. Gerard Bussier, Deputy Director, to coordinate the assessment process. With some initial guidance from FAD the team undertook a self-assessment in conjunction with MoFED departmental heads during October and November 2010 and submitted a comprehensive and commendable report to the IMF-led PEFA mission team for validation in mid-November 2010.

The external team visited Mauritius in November 2010 and subsequently in February 2011 and held extensive discussions with the government technical team, government officials, and other stakeholders. The Vice Prime Minister, the Minister of Finance and Economic Development, and several other senior government officials including the Financial Secretary participated in these discussions. A full list of participating stakeholders is provided in Annex I.

The external PEFA review team was led by Mr. Peter Murphy (IMF) and included Mr. Jason Harris (IMF), Irina Luca (WB), Mr. Patrick Kabuya (WB), and Mr. Maarten de Zeeuw (EU consultant).

The draft report was subject to review by the government of Mauritius, the IMF, and the PEFA Secretariat. The report was presented at a workshop with the Vice Prime Minister, the Minister of Finance and Economic Development, MoFED officials, and other stakeholders in Port Louis in February 2011. 


\section{AbBreviations}

ARC Assessment Review Committee

CISD Central Information Systems Division

EBU Extra-budgetary Unit

EU European Union

FAD Fiscal Affairs Department

GDP Gross Domestic Product

GFSM Government Finance Statistics Manual 2001

GoM Government of Mauritius

INTOSAI International Organization of Supreme Audit Institutions

IPSAS International Public Sector Accounting Standard

IRP Independent Review Panel

MDAs Ministries, Departments and Agencies

MoFED Ministry of Finance and Economic Development

MRA Mauritius Revenue Authority

NAO National Audit Office

OPSG Office of Public Sector Governance

PAC Public Accounts Committee

PEFA Public Expenditure and Financial Accountability

PFM Public Financial Management

PPO Procurement Policy Office

TAS Treasury Accounting System

UNDP United Nations Development Program

WB World Bank 


\section{EXECUTIVE SUMMARY}

At the request of the Government of Mauritius (GoM), the IMF led an external assessment of its public financial management (PFM) framework based on the Public Expenditure and Financial Accountability (PEFA) methodology. In line with the PEFA methodology, this assessment focuses on the performance of the PFM framework, including the associated institutions and procedures, during the last three fiscal years (FY2007-08, FY2008-09 and FY2009). ${ }^{1}$ Improvements in systems and processes taking place after December 31, 2009 have not been considered in this assessment.

\section{Main findings}

Mauritius continues to perform well against the PEFA benchmarks. The scores show progress compared to the 2007 PEFA assessment, with 27 out of the 31 reported ratings higher or equal to those obtained in 2007 . These positive results have been achieved despite the challenges faced in the wake of the recent global financial crisis.

- Central government (central government and extra-budgetary units) budget credibility remains relatively strong. Throughout the assessment period, actual collections exceeded budgeted revenue; however actual primary expenditure exceeded budget estimates by between 5 to 10 percent in the two fiscal years FY2008-09 and FY2009. There were no arrears accumulated during the period.

- $\quad$ There were, however, significant variations-between 10 to 17 percent per annum - in the composition of spending. The main reasons include: (i) reallocation of funds out of the contingency allocations within the 2008-09 budget; and (ii) significant underspending on the capital side of the budget in both the 2007-08 and the 2008-09 budgets of 23-24 percent. Both of these were used to fund to a fiscal stimulus package aimed at supporting the economy.

- Comprehensiveness and transparency have improved since the last PEFA assessment. The budget classification system adopted for the 2008-09 budget, which incorporates a program budget approach for the first time, is based on the IMF Government Finance Statistics Manual (GFSM) 2001. Budget documentation is relatively comprehensive, meeting seven out of nine of the required benchmarks. However, the analysis and discussion of macro-fiscal projections and fiscal outputs are limited, and transactions between the central government and extra-budgetary units are not fully reported.

\footnotetext{
${ }^{1}$ Mauritius aligned its fiscal year to the calendar year commencing January 1, 2010; the PEFA assessment, therefore, covers the two-and-a-half year period, July 1, 2007 to December 31, 2009.
} 
- The monitoring of fiscal risks has been progressively strengthened over the reporting period, though gaps still remain. Monitoring and reporting of fiscal risks is not always systematic and coverage remains incomplete-financial institutions and extra-budgetary units are not monitored. Budget integrity is in general sound, with some remaining issues in the monitoring and publication of contract awards and the tracking of flows of funds to primary service delivery units.

- A clear annual budget calendar exists and is largely adhered to. The budget circular provides the guidance necessary for line ministries to prepare a complete and detailed budget submission. However, strategic planning capacity in government remains limited and the links between macroeconomic projections, fiscal strategy, ministry-level strategic plans, and the budget process require strengthening. In particular, insufficient time is available at the early stages of the budget process for discussions between line ministries and the Ministry of Finance and Economic Development (MoFED) to determine strategic priorities within the fiscal framework. This is particularly apparent on the capital side of the budget, where significant capacity constraints result in substantial underspending.

- Mauritius' tax laws and regulations are generally of high quality. Tax rulings by the Mauritius Revenue Authority (MRA) are publicly available. The formal appeals mechanism has, however, limitations, suggesting the need for a substantial redesign to ensure its effectiveness. There also remains some concern about the level of tax compliance of some professional groups. The penalty regime leaves tax authorities significant discretion and does not take the degree of culpability of the taxpayer into account, in particular, with respect to property transfer taxes. Tax collection efforts are hampered by significant amounts of disputed assessments and accumulation of collectible tax arrears, which together exceeded 4 percent of total revenue in 2008-09.

- Budget execution systems are effective and comprehensive. Cash flow forecasts are prepared upfront for the fiscal year and are monitored through the treasury accounting system (TAS). Warrants are released to ministries and departments at the beginning of the year for the full year, allowing expenditure to be planned and committed in advance. However, significant budget adjustments take place during the year, which are subsequently consolidated into supplementary budgets. Domestic and foreign debts are effectively recorded, managed, and reported. Payroll and personnel records are not integrated, but payroll changes are properly authorized and fully documented. Internal controls are sound with effective compliance testing by both Internal Control Unit and the National Audit Office (NAO).

- Competition, value for money, and controls in procurement are effective. Most procurement follows an open competitive tender process consistent with the 2006 Public Procurement Act and an appropriate mechanism is available for submission and timely resolution of complaints. 
- Internal audit is present in all large ministries and departments. International audit standards for risk analysis and internal audit are in use. Management response varies across ministries and agencies, with actions being taken by accounting officers on major issues, but sometimes with some delay.

- Accounting and financial reporting are of a high standard with some early transition from cash to accrual accounting taking place. Bank reconciliations are up-to-date, and there are no unreconciled accounts maintained in the general ledger. Resources disbursed to service delivery units are recorded, and in-year budget reports comparing budget and actual performance are available from the TAS. The government financial statements are prepared annually within the required timeframe, and are submitted to the NAO within the statutory deadline.

- The NAO undertakes comprehensive annual financial audits of key high-risk government institutions. Low-risk units are audited every three to five years. From July 2009, the NAO adopted a risk-based audit methodology consistent with the directives of the International Organization of Supreme Audit Institutions (INTOSAI). Audit reports are submitted to the legislature within the statutory deadline.

- The scope of the legislature's budget review is limited to a review of mediumterm expenditure projections and priorities. The legislature's review process relies on a full sitting of members, yet they only sit on a part-time basis. There are no specialized committees and only limited technical staff to support budget review. While the Constitution provides 30 days to review the budget, the actual time spent on deliberations is usually no more than two weeks. 
Table 1. Mauritius: Summary of PFM Performance Assessment

(The change trajectory column reflects changes in scores but also qualitative changes that are not necessarily reflected in the score)

\begin{tabular}{|c|c|c|c|c|}
\hline Indicator & $\begin{array}{l}\text { Scores } \\
2010\end{array}$ & \begin{tabular}{|l|} 
Scores \\
2007
\end{tabular} & \begin{tabular}{|l|} 
Change \\
Trajectory
\end{tabular} & Summary Explanation of 2010 Assessment \\
\hline \multicolumn{5}{|c|}{ Credibility of the Budget } \\
\hline $\begin{array}{l}\text { PI-1. Aggregate } \\
\text { expenditure outturn } \\
\text { compared to original } \\
\text { approved budget }\end{array}$ & B & A & $\searrow$ & $\begin{array}{l}\text { Actual central government primary expenditure did not } \\
\text { deviate from budget estimates by more than } 10 \text { percent } \\
\text { in any year. The decline in performance was primarily } \\
\text { due to a fiscal stimulus package that remained } \\
\text { substantially unspent. }\end{array}$ \\
\hline $\begin{array}{l}\text { PI-2. Composition of } \\
\text { expenditure } \\
\text { out-turn compared to } \\
\text { original approved } \\
\text { budget }\end{array}$ & $\mathrm{D}$ & B & $\searrow$ & $\begin{array}{l}\text { The variance in expenditure composition exceeded } \\
\text { overall deviation in primary expenditure in two out of the } \\
\text { last three years and between } 10.0 \text { percent and } 17 \\
\text { percent in all three of the years under consideration. This } \\
\text { decline in performance also reflects continued } \\
\text { reallocation of funds from capital to recurrent. }\end{array}$ \\
\hline $\begin{array}{l}\mathrm{PI}-3 . \text { Aggregate } \\
\text { revenue out-turn } \\
\text { compared to original } \\
\text { approved budget }\end{array}$ & A & A & 入 & $\begin{array}{l}\text { Actual domestic revenue collection was greater than the } \\
\text { budgeted estimates in all three years, some } \\
\text { improvements occurred in forecasting accuracy in the last } \\
\text { two years. }\end{array}$ \\
\hline $\begin{array}{l}\mathrm{Pl}-4 \text {. Stock and } \\
\text { monitoring of } \\
\text { expenditure payment } \\
\text { arrears }\end{array}$ & A & A & $\rightarrow$ & $\begin{array}{l}\text { No stock of expenditure arrears exist, controls are strict } \\
\text { and all outstanding invoices are cleared at the year-end. } \\
\text { No change from } 2007 .\end{array}$ \\
\hline \multicolumn{5}{|c|}{ Comprehensiveness and Transparency } \\
\hline $\begin{array}{l}\text { PI-5. Classification } \\
\text { of the budget }\end{array}$ & A & B & $\uparrow$ & $\begin{array}{l}\text { The classification system was aligned with the } \\
\text { Government Finance Statistics Manual (GFSM) } 2001 \text { in } \\
\text { the } 2008-09 \text { budgets, together with the introduction of a } \\
\text { program-based budget classification. The COFOG } \\
\text { functional classification can be derived from the sub- } \\
\text { program classification. }\end{array}$ \\
\hline $\begin{array}{l}\text { PI-6. } \\
\text { Comprehensiveness } \\
\text { of information } \\
\text { included in budget } \\
\text { documentation }\end{array}$ & A & B & $\uparrow$ & $\begin{array}{l}\text { Seven out of the nine benchmarks, as opposed to six in } \\
2007 \text {, are met by the annual budget documents. }\end{array}$ \\
\hline $\begin{array}{l}\text { PI-7. Extent of } \\
\text { unreported } \\
\text { government } \\
\text { operations }\end{array}$ & $\mathrm{D}+$ & $\mathrm{D}+$ & $\pi$ & $\begin{array}{l}\text { Extra-budgetary expenditure has not been fully } \\
\text { incorporated in the annual budget estimates or in in-year } \\
\text { budget execution statements. However, improved } \\
\text { disclosure is being made in the year-end financial } \\
\text { statements of extra-budgetary units (EBUs) and in the } \\
\text { extra-budgetary expenditure shown in the Digest of } \\
\text { Public Statistics. No change in overall score from the } \\
2007 \text { assessment. }\end{array}$ \\
\hline $\begin{array}{l}\text { Pl-8. Transparency } \\
\text { of inter- } \\
\text { governmental fiscal } \\
\text { relations }\end{array}$ & B & A & $\searrow$ & $\begin{array}{l}\text { Although horizontal grant allocations to subnational } \\
\text { governments are transparent, they have not been based } \\
\text { on any objective rule-based criteria for more than ten } \\
\text { years; this was not reflected in the } 2007 \text { assessment. }\end{array}$ \\
\hline
\end{tabular}




\begin{tabular}{|c|c|c|c|c|}
\hline $\begin{array}{l}\text { PI-9. Oversight of } \\
\text { aggregate fiscal risk } \\
\text { from other public } \\
\text { sector entities }\end{array}$ & $\mathrm{C}+$ & $\mathrm{B}+$ & ע & $\begin{array}{l}\text { Government undertakes annually a partial analysis of } \\
\text { various aspects of fiscal risk during the budget process, } \\
\text { but this analysis and monitoring is not systematic. This } \\
\text { was not reflected in the } 2007 \text { assessment. }\end{array}$ \\
\hline $\begin{array}{l}\text { PI-10. Public access } \\
\text { to key fiscal } \\
\text { information }\end{array}$ & B & A & $\searrow$ & $\begin{array}{l}\text { Recent fiscal reports fulfill three of the six required } \\
\text { information benchmarks. This is two less than that } \\
\text { reflected in the } 2007 \text { assessment. }\end{array}$ \\
\hline \multicolumn{5}{|c|}{ Policy Based Budgeting } \\
\hline $\begin{array}{l}\text { PI-11. Orderliness } \\
\text { and participation in } \\
\text { the annual budget } \\
\text { process }\end{array}$ & $\mathrm{B}+$ & B & $\uparrow$ & $\begin{array}{l}\text { A clear annual budget calendar has been introduced and } \\
\text { clear guidance is now provided-an improvement on } \\
2007 \text { assessment. The timetable is largely adhered to } \\
\text { and the estimates are approved by the legislature before } \\
\text { the new financial year commences. }\end{array}$ \\
\hline $\begin{array}{l}\text { Pl-12. Multiyear } \\
\text { perspective in fiscal } \\
\text { planning, } \\
\text { expenditure policy, } \\
\text { and budgeting }\end{array}$ & $\mathrm{C}+$ & $\mathrm{D}+$ & $\uparrow$ & $\begin{array}{l}\text { The budget now includes forecasts of the main fiscal } \\
\text { aggregates over three years on a rolling basis, an } \\
\text { improvement on } 2007 \text { assessment, but multi-year } \\
\text { estimates are not linked to subsequent annual estimates. } \\
\text { Debt sustainability analysis is effective, but limited } \\
\text { assessment of recurrent cost implication of investments } \\
\text { is undertaken. }\end{array}$ \\
\hline \multicolumn{5}{|c|}{ Predictability and Control in Budget Execution } \\
\hline $\begin{array}{l}\text { PI-13. Transparency } \\
\text { of taxpayer } \\
\text { obligations and } \\
\text { liabilities }\end{array}$ & $\mathrm{B}+$ & B & $\uparrow$ & $\begin{array}{l}\text { Laws and regulations and rulings containing Mauritius } \\
\text { Revenue Authority's (MRA) interpretation of them have } \\
\text { progressively improved as has the quality of information } \\
\text { given to the taxpayers. The Assessment Review } \\
\text { Committee (ARC) is however understaffed and at risk of } \\
\text { collapsing under an accumulating case load. }\end{array}$ \\
\hline $\begin{array}{l}\text { PI-14. Effectiveness } \\
\text { of measures for } \\
\text { taxpayer registration } \\
\text { and tax assessment }\end{array}$ & $\mathrm{B}+$ & $\mathrm{B}+$ & $\pi$ & $\begin{array}{l}\text { Sound registration systems have been strengthened, but } \\
\text { MRA's Corporate Plan from February } 2008 \text { continues to } \\
\text { highlight non-filing and non-payment by some } \\
\text { professional groups. The penalty regime leaves MRA } \\
\text { considerable discretion. Programs for taxpayer audit and } \\
\text { investigations are now compatible with standard norms. }\end{array}$ \\
\hline $\begin{array}{l}\text { Pl-15. Effectiveness } \\
\text { in collection of tax } \\
\text { payments }\end{array}$ & $\mathrm{C}+$ & $\mathrm{D}+$ & $\uparrow$ & $\begin{array}{l}\text { Tax debt collections have improved since } 2007 \text {, but the } \\
\text { tax debt collection ratio remains low, due to a failure to } \\
\text { write-off old debts. }\end{array}$ \\
\hline $\begin{array}{l}\text { PI-16. Predictability } \\
\text { in the availability of } \\
\text { funds for } \\
\text { commitment of } \\
\text { expenditures }\end{array}$ & $\mathrm{C}+$ & A & y & $\begin{array}{l}\text { Cash flows forecasts are prepared and commitments } \\
\text { ceilings in the form of warrants for the full fiscal year are } \\
\text { available through the Treasury Accounting System (TAS). } \\
\text { However significant in-year budget adjustment increases, } \\
\text { of between } 7 \text { and } 18 \text { percent, were approved by the } \\
\text { MoFED during the assessment period, a decline on } 2007 \\
\text { assessment. }\end{array}$ \\
\hline $\begin{array}{l}\text { Pl-17. Recording } \\
\text { and management } \\
\text { of cash balances, } \\
\text { debt, and } \\
\text { guarantees }\end{array}$ & A & A & $\lambda$ & $\begin{array}{l}\text { A new Public Debt Act has been enacted. } \\
\text { Comprehensive debt records are maintained and } \\
\text { quarterly and annual reports produced. Clear policies for } \\
\text { contracting loans and issuance of guarantees, mainly } \\
\text { entrusting responsibility to the Minister of Finance, exist } \\
\text { and are followed. }\end{array}$ \\
\hline
\end{tabular}




\begin{tabular}{|c|c|c|c|c|}
\hline $\begin{array}{l}\text { PI-18. Effectiveness } \\
\text { of payroll controls }\end{array}$ & $\mathrm{B}+$ & $\mathrm{B}+$ & $\rightarrow$ & $\begin{array}{l}\text { Payroll and personnel records are not integrated, but } \\
\text { payroll changes are properly authorized and fully } \\
\text { documented. A new HR system is being rolled out, but } \\
\text { this is yet to be evaluated. }\end{array}$ \\
\hline $\begin{array}{l}\text { PI-19. Competition, } \\
\text { value for money and } \\
\text { controls in } \\
\text { procurement }\end{array}$ & A & $\mathrm{B}+$ & $\uparrow$ & $\begin{array}{l}\text { More than } 75 \text { percent of contracts above the national } \\
\text { threshold for small purchases are now awarded } \\
\text { competitively. Non-competitive methods are now justified } \\
\text { as per the } 2006 \text { Public Procurement Act. A complaints } \\
\text { mechanism is now operational through an independent } \\
\text { body (IRP) whose decisions are made public. }\end{array}$ \\
\hline $\begin{array}{l}\text { Pl-20. Effectiveness } \\
\text { of internal controls } \\
\text { for non-salary } \\
\text { expenditure }\end{array}$ & A & A & $\rightarrow$ & $\begin{array}{l}\text { An effective commitment control system exists. } \\
\text { Comprehensive internal control rules and procedures of } \\
\text { recording transactions also exist and are adhered to. }\end{array}$ \\
\hline $\begin{array}{l}\text { Pl-21. Effectiveness } \\
\text { of Internal Audit }\end{array}$ & $\mathrm{B}+$ & $\mathrm{B}+$ & $\rightarrow$ & $\begin{array}{l}\text { Internal Audit Units are operational in most of central } \\
\text { government entities but not all, especially extra- } \\
\text { budgetary units. Reports are issued per approved audit } \\
\text { plan. The Management typically acts on the units' } \\
\text { recommendations, but with some delays. }\end{array}$ \\
\hline \multicolumn{5}{|c|}{ Accounting, Recording and Reporting } \\
\hline $\begin{array}{l}\text { PI-22. Timeliness } \\
\text { and regularity of } \\
\text { accounts } \\
\text { reconciliation }\end{array}$ & A & A & $\rightarrow$ & $\begin{array}{l}\text { Bank reconciliations are done daily and in-depth monthly, } \\
\text { within four weeks after month-end. There are no un- } \\
\text { reconciled accounts in the general ledger. }\end{array}$ \\
\hline $\begin{array}{l}\text { PI-23. Availability of } \\
\text { information on } \\
\text { resources received } \\
\text { by service delivery } \\
\text { units }\end{array}$ & A & A & $\rightarrow$ & $\begin{array}{l}\text { The Accounting System records and provides reliable } \\
\text { information of all types of resources received and used } \\
\text { by service delivery units. Direct resources from donors in } \\
\text { cash and kind are not significant. }\end{array}$ \\
\hline $\begin{array}{l}\text { PI-24. Quality and } \\
\text { timeliness of in-year } \\
\text { budget reports }\end{array}$ & A & $\mathrm{B}+$ & $\uparrow$ & $\begin{array}{l}\text { Classification of data in TAS allows direct comparison } \\
\text { with the original budget. However, the data excludes } \\
\text { decentralized units such as EBU's. The reports, with data } \\
\text { of adequate quality, are issued monthly and are available } \\
\text { on the Ministry website. }\end{array}$ \\
\hline $\begin{array}{l}\text { Pl-25. Quality and } \\
\text { timeliness of annual } \\
\text { financial statements }\end{array}$ & A & A & $\rightarrow$ & $\begin{array}{l}\text { Consolidated financial statements are prepared annually } \\
\text { and include information on revenue, expenditure, } \\
\text { financial assets and liabilities. The statements, submitted } \\
\text { on time for audit are prepared using cash basis of } \\
\text { accounting and now comply with some aspects of cash } \\
\text { based IPSAS. }\end{array}$ \\
\hline \multicolumn{5}{|c|}{ External Scrutiny and Audit } \\
\hline $\begin{array}{l}\text { PI-26. Scope, } \\
\text { nature, and follow-up } \\
\text { of external audit }\end{array}$ & $\mathrm{B}+$ & $\mathrm{B}+$ & $\pi$ & $\begin{array}{l}\text { The National Audit Office (NAO) now undertakes a } \\
\text { comprehensive independent financial audit of all key } \\
\text { government institutions on an annual basis using modern } \\
\text { audit techniques. Performance auditing has also been } \\
\text { introduced. }\end{array}$ \\
\hline $\begin{array}{l}\text { PI-27. Legislative } \\
\text { scrutiny of the } \\
\text { annual budget law }\end{array}$ & $\mathrm{C}+$ & $\mathrm{B}+$ & $\downarrow$ & $\begin{array}{l}\text { Legislative review takes place, but the } \\
\text { comprehensiveness of the review is limited by lack of } \\
\text { time and support resources. }\end{array}$ \\
\hline
\end{tabular}




\begin{tabular}{|l|c|c|c|l|l|}
\hline $\begin{array}{l}\text { PI-28. Legislative } \\
\text { scrutiny of external } \\
\text { audit reports }\end{array}$ & D+ & D+ & $\downarrow$ & $\begin{array}{l}\text { The absence of Public Accounts Committee (PAC) } \\
\text { review reports and open hearings limits the effectiveness } \\
\text { of the PAC. Follow-up of the Audit report is also } \\
\text { constrained by the weakness of PAC reporting and } \\
\text { follow-up. }\end{array}$ \\
\hline $\begin{array}{l}\text { D-1. Predictability of } \\
\text { direct budget } \\
\text { support }\end{array}$ & D & A & $\downarrow$ & $\begin{array}{l}\text { Much of the aid is delivered by direct budget support. } \\
\text { Significant variations have occurred but are primarily due } \\
\text { to GoM's active management of aid resources. }\end{array}$ \\
\hline $\begin{array}{l}\text { D-2. Financial } \\
\text { information provided } \\
\text { by donors for } \\
\text { budgeting and } \\
\text { reporting on project } \\
\text { and program aid }\end{array}$ & A & A & $\rightarrow$ & $\begin{array}{l}\text { Forecasting and reporting procedures are of acceptable } \\
\text { standard. }\end{array}$ \\
\hline $\begin{array}{l}\text { D-3. Proportion of } \\
\text { aid that is managed } \\
\text { by use of national } \\
\text { procedures }\end{array}$ & B & $\begin{array}{l}\text { No } \\
\text { Rating }\end{array}$ & $\uparrow$ & The increasing use of direct budget support is \\
progressively increasing the use of national procedures.
\end{tabular}




\section{INTRODUCTION}

1. The purpose of this PEFA assessment is to review the performance of Mauritius' PFM framework. The assessment provides a baseline for monitoring progress in the different areas of PFM reform and supporting the authorities in defining, along with other inputs, a coherent PFM reform strategy.

2. This assessment mainly covers the activities of the central government. This includes 44 ministries and departments (budgetary central government), and 110 extra-budgetary units (EBUs). In this context EBUs comprise deconcentrated special funds and agencies performing specialist government functions under the effective control of government ministries. Seven of the EBUs, listed later in this report have a material impact on the fiscal operations of government, as discussed under indicator PI-1.This definition of central government excludes 21 financial and 49 non-financial public corporations (public enterprises) and ten subnational governments which together with budgetary central government represent the public sector. As provided for in the PEFA analytical framework, key inter-governmental fiscal relations between central government, public corporations and subnational governments are addressed in two specific indicators (PI8 and PI9).

3. The assessment is based on publicly available documents or supplementary information provided by the authorities and other stakeholders. These include the annual budget documents, in-year financial reports, the annual financial statements and the digest of public finance statistics for 2007-09. The information gathered has been cross-checked against different sources to the extent possible.

\section{COUNTRY BACKGROUND INFORMATION}

\section{A. Country Economic Situation ${ }^{2}$}

4. Mauritius has achieved remarkable success since its independence in 1968, with one of the highest per capita incomes in Africa. Gross domestic product (GDP) per capita has increased from US\$1,295 in 1980 to US\$7,303 in 2010. Underpinning this performance has been macroeconomic and political stability, robust institutions, an efficient administration, a favorable regulatory environment, and a well-developed financial system. This has seen the emergence of a number of major sectors in the economy, including sugar, tourism, textile manufacturing, and financial services.

5. The Mauritian economy has been subject to a number of major shocks over recent years. These include the 2005 phasing out of the multi-fiber agreement, sharp reductions in EU protocol prices; which had significant impacts on sugar, manufacturing, and textile sectors and

\footnotetext{
${ }^{2}$ Mauritius 2010 Article IV Consultation (IMF); Bank of Mauritius (2010), Monthly Statistical Bulletin; Government of Mauritius (2010), 2011 Budget.
} 
the more recent global financial crises. As part of the response to the earlier shocks, the government embarked on a major program of reforms focusing on improving fiscal performance, enhancing competitiveness, improving the business climate, and widening opportunities through increasing participation, social inclusion and sustainability. These reforms earned Mauritius the title of "best place to do business in Africa" from the World Bank in 2008 and 2009.

6. The economy reacted favorably to these reforms. Real GDP growth recovered to 5.1 percent in 2008, and the unemployment rate fell to a five-year low of 7.1 percent-down from a peak of 9.6 percent in 2005 . While this period saw an increase in inflation-up to 9.7 percent in 2008-this was largely due to increases in food and energy prices. A large factor behind the return to strong growth was the rapid expansion of the offshore financial sector, aided primarily by a favorable double tax agreement with India, and strong growth in the tourism sector.

\section{The advent of the global financial crisis provided a further shock to the Mauritian} economy. Although not directly impacted, due to a sound financial system and lack of exposure to the asset backed securities, the subsequent recession in key export markets-primarily Europedid lead to a slowdown in economic activity, with GDP growth falling to 3.1 percent in 2009. This was driven by a 13 percent fall in tourist earnings, which had been growing at an average annual rate of 19 percent over the previous five years, and a contraction in the manufacturing sector. These were partly offset by continued strong growth in the construction and offshore financial sectors.

8. The Mauritian economy is expected to recover strongly, with authorities projecting growth to approach potential, estimated at 5 percent, over the next few years. An important contributing factor to the recovery has been the comprehensive policy package adopted in response to the crisis, which included fiscal stimulus, monetary easing, maintaining foreign exchange liquidity, strengthening the social safety net, and measures to facilitate private debt consolidation and to preserve jobs. These measures prevented a large increase in the unemployment rate, which remained around 71/4 percent over 2008 and 2009. Construction, tourism, and financial services are expected to underpin growth going forward.

9. Downside risks remain, particularly around the external sector. Given Mauritius' exposure to the Euro zone, through the manufacturing and tourism sectors, the continued turbulence in that area presents significant downside risks to the economy. The high degree of volatility in food and energy prices also present risks to the inflationary outlook. 


\section{B. Budgetary Outcomes}

10. The reported fiscal position has loosened recently, in response to the global financial crisis. The budget balance, as reported by the authorities has widened from a deficit of 3.3 percent in 2007-08, to a deficit of 3.9 percent in July-December 2009 (Table 2). The deficit is estimated to have increased further in 2010 to 4.5 percent. Once net lending to state-owned enterprises is taken into account, the increase in the deficit is somewhat smaller, at half a percent of GDP due to loan repayments from SOEs over the period.

Table 2. Mauritius: Budgetary Central Government Outturns (Percent of GDP)

\begin{tabular}{lrrr}
\hline & $\mathbf{2 0 0 7 - 0 8}$ & $\mathbf{2 0 0 8 - 0 9}$ & July-Dec 2009 \\
\hline Total revenue and grant & 21.2 & 22.9 & 22.3 \\
Total revenue & 21.0 & 21.9 & 20.2 \\
Grants & 0.2 & 1.0 & 2.1 \\
Total expenditure and net lending & 24.5 & 26.7 & 26.2 \\
Current expenditure (ex interest) & 17.9 & 20.0 & 19.4 \\
Capital expenditure and net lending & 2.4 & 2.7 & 3.3 \\
Interest & 4.2 & 3.9 & 3.6 \\
Overall balance & -3.3 & -3.7 & -3.9 \\
Primary balance & 2.7 & 2.7 & 1.1 \\
Adjusted for accrual & 0.0 & 0.1 & 0.2 \\
Net financing & 3.3 & 3.7 & 3.7 \\
Domestic & 3.4 & 2.4 & 3.5 \\
External & -0.1 & 1.3 & 0.1 \\
\hline
\end{tabular}

Source: Ministry of Finance and Development

11. The increase in expenditure and net lending is largely due to an increase in capital expenditure. Despite the close to 1 percent of GDP increase, the amount of spending on capital expenditure over the period has been significantly lower than the amount budgeted for (Tables 2 and 3). This reflects over-optimistic budget estimates and capacity limitations within the government to deliver.

12. One of the interesting features of the Mauritian budget over recent years has been the government's response to the underspending on the capital side. Rather than allowing the underspends to flow through to the budget bottom line, resulting in smaller deficits, the government has reappropriated the funds, and transferred them to a set of special funds, which can subsequently spend the money on specific items over a period years. 
Table 3. Mauritius: Government Expenditures by Economic Classification

(Percent of Total Expenditure and Net Lending)

\begin{tabular}{lrrrr}
\hline & & & Jul-Dec & \\
& $\mathbf{2 0 0 7 - 0 8}$ & $\mathbf{2 0 0 8 - 0 9}$ & $\mathbf{2 0 0 9}$ & $\mathbf{2 0 1 0}$ \\
\hline Salaries and wages & 20.6 & 22.5 & 22.3 & 23.0 \\
Goods and services & 11.6 & 10.9 & 10.4 & 13.3 \\
Transfers and subsidies & 40.8 & 41.8 & 41.2 & 38.4 \\
Capital expenditure and net lending & 9.7 & 10.0 & 12.4 & 12.2 \\
Interest & 17.3 & 14.8 & 13.7 & 13.2 \\
Total Expenditure and Net Lending (MUR mln) & 61,548 & 72,361 & 38,928 & 77,307 \\
\hline
\end{tabular}

Source: Ministry of Finance and Economic Development

Table 4. Mauritius: Impact of Special Funds on Budget Aggregate Outturn

(Percent of GDP)

\begin{tabular}{|c|c|c|c|c|}
\hline & 2007-08 & 2008-09 & $\begin{array}{r}\text { Jul-Dec } \\
2009 \\
\end{array}$ & 2010 \\
\hline \multicolumn{5}{|l|}{ Central budgetary government } \\
\hline Total revenue and grants & 21.2 & 22.9 & 22.3 & 21.2 \\
\hline Total expenditure and net lending & 24.5 & 26.7 & 26.2 & 26.1 \\
\hline Current expenditure & 22.1 & 24.0 & 23.0 & 22.9 \\
\hline Of which transfers to funds & 1.2 & 2.1 & 1.8 & 0.9 \\
\hline Capital expenditure and net lending & 2.4 & 2.7 & 3.3 & 3.2 \\
\hline Overall balance & -3.3 & -3.7 & -3.7 & -4.8 \\
\hline Net financing & -3.3 & 3.7 & 3.7 & 4.8 \\
\hline \multicolumn{5}{|l|}{ Special funds } \\
\hline Total revenues & 1.2 & 2.2 & 1.9 & 0.9 \\
\hline Transfers from central government & 1.2 & 2.1 & 1.8 & 0.9 \\
\hline Interest receipts & 0.0 & 0.1 & 0.1 & 0.0 \\
\hline Expenditures & 0.0 & 0.3 & 0.5 & 1.2 \\
\hline Current expenditure & 0.0 & 0.1 & 0.2 & 0.5 \\
\hline Capital expenditure and net lending & 0.0 & 0.2 & 0.3 & 0.7 \\
\hline Overall balance & 1.2 & 1.9 & 1.4 & -0.3 \\
\hline \multicolumn{5}{|l|}{ Adjusted central budgetary government } \\
\hline Total revenue and grants & 21.2 & 23.0 & 22.5 & 21.3 \\
\hline Total expenditure and net Lending & 23.2 & 24.8 & 24.9 & 26.4 \\
\hline Current expenditure & 20.9 & 21.9 & 21.4 & 22.5 \\
\hline Capital expenditure and net lending & 2.4 & 2.9 & 3.5 & 3.9 \\
\hline Overall balance & -2.1 & -1.8 & -2.4 & -5.1 \\
\hline Net financing & 2.1 & 1.8 & 2.4 & 5.1 \\
\hline
\end{tabular}

Source: Ministry of Finance and Economic Development

13. These transfers have been recorded as current expenditure as far as budgetary central government is concerned. However, a significant proportion of these transfers represent 
an accumulation of financial assets in special funds (which are EBUs) and should, from a central government perspective and in accordance with the GFSM 2001 standards, be treated as belowthe-line financing items. Over MUR 11 billion or 7.3 percent of GDP have been transferred to these funds (identified in Annex III, Table A1) during the two-and-a-half years under consideration.

\section{Adjusting for the transfers to the funds, and the subsequent payments out of} the funds results in significantly lower central government deficits to between 1.8 and 2.4 percent GDP over the period under consideration (Table 4). This is because the transfers exceeded the payments out of the funds, thus generating substantial savings. In later years (and particularly in 2010 and 2011) it is understood the reverse is planned to take place-as payments out of funds will exceed transfers in-the overall central government deficit will, therefore, be considerably larger than reported, projected to reach 5.8 percent of GDP in 2011.

15. There has been, however, limited public reporting on the use or balances in these funds. The disclosure of these past transactions, balances, and budgeted payments in the 2011 budget is a welcome improvement in transparency.

16. Public debt is close to 60 percent of GDP at the end of the period under consideration. In 2008, the government introduced a public debt law requiring public sector debt, including that of the state-owned enterprises, to remain below 60 percent of GDP. For the years of the assessment the government has kept public debt below the limit.

\section{Legal and Institutional Framework}

17. Mauritius has a parliamentary model with the majority parties in the national assembly electing the prime minister, who in turn forms the government and appoints a cabinet of ministers. The national assembly, comprising representatives from 20 mainland constituencies and from the island of Rodrigues, is the prime law making body; a supreme court heads the judicial system. The prime minister appoints a minister responsible for the finance and economic development portfolio, currently a vice prime minister, who is responsible for the overall policy and management of public finances.

18. The PFM system is primarily regulated by the Constitution, the Consolidated Finance and Audit Act 2008, the Public Debt Management Act 2008, and the Public Procurement Act 2008. Chapter X of the Constitution deals with finances including the PFM roles of the executive, legislature, and judicial branches of government and Article 110 with the appointment and the duties of the Director of Audit. A Financial Management Manual, together with a range of circulars and other instructions, has been issued by the MoFED from time to time. EBUs are governed by regulations issued by the MoFED under the Finance and Audit Act (special fund provisions) or by their own individual legal frameworks approved by parliament. 
19. The minister of finance and economic development, supported by the MoFED, under the management of the financial secretary, is the primary executive authority in relation to PFM. Accounting officers (known locally as controlling officers) are appointed and accountable for the delivery of program outputs in line ministries and departments and the management of appropriated funds. The director of audit (equivalent to the auditor general position in other jurisdictions) is responsible for the annual audit of the central government accounts, including EBUs, as well as those of subnational government. Under the 1995 standing orders and rules of the national assembly, a Public Accounts Committee (PAC) is established at the beginning of each session to examine the audited accounts and report submitted by the director of audit.

20. The central government PFM system in Mauritius comprises a centralized treasury accounting system (TAS) for budgetary central government units and individual budget and financial management system arrangements for each EBU. A detailed annual unified revenue and expenditure budget is prepared on a rolling three-year program and sub-program basis that outlines the key mission, strategies, program outputs, performance indicators and targets to be achieved. Detailed estimates by economic category, including transfers to EBUs and subnational government, are shown for each program and are summarized in various consolidated budget statements. Budgetary central government entities account for their transactions through the TAS and consolidated annual financial statements are prepared by the accountant general. Budgeted transfers to EBUs are approved by responsible ministries and disbursed by the MoFED.

21. EBUs, subnational governments and public corporations have their own individual budget, financial management, and financial reporting arrangements but are all required to submit annual financial statements to the MoFED and director of audit. In addition, Public Finance Statistics are prepared by the Central Statistical Office (CSO) on an annual basis and provide for a range of economic and functional analysis as well as central government and general government consolidations.

\section{Assessment of PFM Systems, Processes, And Institutions}

\section{A. Budget Credibility}

\section{PI-1. Aggregate expenditure outturn compared to original approved budget}

This indicator measures the extent of difference between actual primary expenditure and the originally budgeted primary expenditure (i.e., excluding debt service charges, but normally also excluding externally financed project expenditure).

\begin{tabular}{|c|c|c|}
\hline $\begin{array}{l}\text { 2010 Assessment (scoring method M1) } \\
\text { Dimension: }\end{array}$ & $\begin{array}{l}\text { Score } \\
2010\end{array}$ & $\begin{array}{l}\text { Score } \\
2007\end{array}$ \\
\hline $\begin{array}{l}\text { In no more than one out of the last three years has the actual central } \\
\text { government expenditure deviated from budgeted expenditure by an amount } \\
\text { equivalent to more than } 10 \text { percent of budgeted expenditure }\end{array}$ & B & A \\
\hline
\end{tabular}


22. Actual central government primary expenditure, including transfers to EBUs, deviated from budgetary central government estimates by more than 5 percent in two of the years considered. Central government (Table 5) includes both the operations of central budgetary government and EBUs (transfers have been eliminated). Given the degree of control exercised by the government over donor funded project expenditure, and that they represent less than 2 percent of total expenditure, these are included in the calculation; this is consistent with the treatment undertaken in the 2007 assessment.

Table 5. Mauritius: Central Government Primary Budget and Actual Expenditure

\begin{tabular}{lrrr}
\hline & $\begin{array}{r}\text { 2007-08 } \\
\text { MUR mln }\end{array}$ & $\begin{array}{r}\text { 2008-09 } \\
\text { MUR mln }\end{array}$ & $\begin{array}{r}\text { July-Dec 2009 } \\
\text { MUR mln }\end{array}$ \\
\hline Budget (Original) & 47,774 & 59,721 & 33,949 \\
Actual & 46,334 & 55,017 & 31,784 \\
Difference & $-1,440$ & $-4,704$ & $-2,165$ \\
Percent difference & -3.0 & -7.9 & -6.4 \\
\hline
\end{tabular}

Source: Ministry of Finance and Economic Development

23. While the deviation of central government aggregate expenditure was relatively low, it is important to note that there was a significant degree of deviation between the aggregate capital and aggregate recurrent budgets. In the first two years of the assessment period, the capital expenditure outturn was significantly lower than budgeted, underspending by nearly 25 percent in 2007-08, and by 23 percent in 2008-09 (Table 6).

Table 6. Mauritius: Comparison of Budget and Actual Capital Expenditure

\begin{tabular}{lrrr}
\hline & $\begin{array}{r}\text { 2007-08 } \\
\text { MUR mln }\end{array}$ & $\begin{array}{r}\text { 2008-09 } \\
\text { MUR mln }\end{array}$ & $\begin{array}{r}\text { July-Dec 2009 } \\
\text { MUR mln }\end{array}$ \\
\hline Budget (Original) & $6,015.0$ & $7,225.0$ & $4,760.0$ \\
Actual & $4,539.0$ & $5,546.0$ & $4,945.9$ \\
Difference & $-1,476.0$ & $-1,679.0$ & 185.9 \\
Percent difference & -24.5 & -23.2 & 3.9 \\
\hline
\end{tabular}

Source: Ministry of Finance and Economic Development

24. The low variance was maintained even though a significant stimulus package was introduced in September 2008 in response to the global financial crisis. The stimulus package, approximately 5 percent of GDP, was funded through a combination of unallocated "rainy day" contingency funds provided in the original 2008-09 budget, and of reallocations from capital expenditure. A significant portion of the stimulus package was transferred to special funds from which spending took place, mainly in the subsequent year. 


\section{PI-2. Composition of expenditure outturn compared to original approved budget}

This indicator measures the extent to which variance in expenditure composition exceeded overall deviation in primary expenditure (as defined in PI-1) during the last three years.

\begin{tabular}{|l|c|c|}
\hline $\begin{array}{l}\text { 2010 Assessment (Scoring method M1) } \\
\text { Dimension: }\end{array}$ & $\begin{array}{c}\text { Score } \\
\mathbf{2 0 1 0}\end{array}$ & $\begin{array}{c}\text { Score } \\
\mathbf{2 0 0 7}\end{array}$ \\
\hline $\begin{array}{l}\text { The variance in expenditure composition exceeded overall deviation in } \\
\text { primary expenditure by 10 percent in at least two out of the last three } \\
\text { years }\end{array}$ & D & B \\
\hline
\end{tabular}

25. The variance in budgetary central government expenditure composition exceeded the overall deviation in primary expenditure by considerable margins in all three of the years under consideration. In 2007-08, the compositional variation was equivalent to 10.2 percent of primary expenditure; in 2008-09 it increased to 17.5 percent, before falling back to 6.3 percent in the July-December 2009 half financial year (Table 7).

26. There were three major reasons for the increase in compositional variance. The first was the financial crisis, as discussed above. The second was the consistent underspending on the capital side of budget, which was been swept up and reallocated to the recurrent side of the budget near the end of the financial year. The third was the adoption of substantial contingency funds in the budget process, which were effectively unallocated during the budget processrepresenting a general policy reserve-and then distributed as the year progressed. In 2008-09, this contingency reserve was used to fund much of the stimulus package.

\section{Major in-year variances were:}

- In 2007-08: a MUR1.7b (71 percent) increase in funding to agriculture and forestry; MUR987m (2,200 percent) increase in funding to fuel and energy, through the establishment of a renewable energy fund; and R891m (11 percent) increase in funding to education. These were funded through reductions to housing and community services, and an increase in total expenditure.

- In 2008-09 and 2009: for 2008-09 a MUR2.6b (2,600 percent) increase to manufacturing, this was funded through reductions to general public servicesthe contingency reserve and social security; and, for 2009 a MUR643m increase to transport and communication, due to increased road construction. This was funded through reductions to education and social security. 
Table 7. Mauritius: Comparison of Budget and Actual Aggregate Expenditure

(Average percent variance)

\begin{tabular}{|c|c|c|c|c|c|c|c|c|c|c|c|c|}
\hline & \multicolumn{4}{|c|}{ 2007-08 } & \multicolumn{4}{|c|}{ 2008-09 } & \multicolumn{4}{|c|}{ July - Dec 2009} \\
\hline & Budget & Actual & Abs var & $\%$ var & Budget & Actual & Abs var & $\%$ var & Budget & Actual & Abs var & $\%$ var \\
\hline & $\begin{array}{c}\text { MUR } \\
\text { mln }\end{array}$ & $\begin{array}{r}\text { MUR } \\
\mathrm{mln}\end{array}$ & $\begin{array}{r}\text { MUR } \\
\mathrm{mln}\end{array}$ & $\begin{array}{c}\text { MUR } \\
\text { mln }\end{array}$ & $\begin{array}{r}\text { MUR } \\
\text { mln }\end{array}$ & MUR mln & $\begin{array}{c}\text { MUR } \\
\text { mln }\end{array}$ & $\begin{array}{r}\text { MUR } \\
\mathrm{mln}\end{array}$ & MUR mln & $\begin{array}{r}\text { MUR } \\
\mathrm{mln}\end{array}$ & $\begin{array}{r}\text { MUR } \\
\mathrm{mln}\end{array}$ & $\begin{array}{r}\text { MUR } \\
\mathrm{mln}\end{array}$ \\
\hline Gen public services & $4,628.6$ & $4,515.1$ & 113.5 & -2.5 & $10,791.0$ & $9,303.6$ & $1,487.4$ & -13.8 & $5,746.9$ & $5,723.8$ & 23.1 & -0.4 \\
\hline Defense, public order \& safety & 4,819 & 4,541 & 278 & -5.8 & 6,368 & 5,578 & 790 & -12.4 & 3,567 & 3,405 & 162 & -4.5 \\
\hline Education & 7,812 & 8,703 & 891 & 11.4 & 9,367 & 9,659 & 292 & 3.1 & 5,513 & 5,190 & 324 & -5.9 \\
\hline Health & 4,757 & 4,680 & 77 & -1.6 & 6,353 & 5,824 & 529 & -8.3 & 3,670 & 3,522 & 148 & -4.0 \\
\hline Social Security & 12,026 & 11,745 & 281 & -2.3 & 14,990 & 14,005 & 984 & -6.6 & 8,114 & 7,836 & 278 & -3.4 \\
\hline Housing \& com services & 4,096 & 3,144 & 952 & -23.2 & 1,852 & 2,392 & 539 & 29.1 & 784 & 717 & 67 & -8.5 \\
\hline Rec, cult \& rel services & 669 & 552 & 117 & -17.5 & 915 & 692 & 223 & -24.4 & 507 & 358 & 149 & -29.4 \\
\hline Fuel and energy & 44 & 1,032 & 988 & $2,245.2$ & 338 & 28 & 309 & -91.7 & 17 & 216 & 199 & $1,169.4$ \\
\hline Agriculture \& forestry & 2,462 & 4,228 & 1,766 & 71.7 & 2,067 & 2,680 & 612 & 29.6 & 939 & 854 & 86 & -9.1 \\
\hline Mining, man \& const & 170 & 112 & 58 & -34.1 & 830 & 3,449 & 2,619 & 315.5 & 210 & 161 & 50 & -23.6 \\
\hline Transportation \& comm & 1,815 & 1,623 & 192 & -10.6 & 2,463 & 3,262 & 799 & 32.5 & 2,901 & 3,545 & 644 & 22.2 \\
\hline Environmental protection & & & & & 2,970 & 2,082 & 889 & -29.9 & 1,375 & 1,608 & 233 & \\
\hline Other eco services & 1,969 & 1,596 & 373 & -18.9 & 418 & 1,009 & 591 & 141.4 & 604 & 582 & 23 & -3.8 \\
\hline Other expenditure & 2,508 & 2,984 & 476 & 19.0 & & & & & & & & \\
\hline Total expenditure & 47,774 & 49,454 & 6,562 & 3.5 & 59,721 & 59,962 & 10,664 & 0.4 & 33,949 & 33,716 & 2,384 & -0.7 \\
\hline Absolute variance & & & $13.7 \%$ & & & & $17.9 \%$ & & & & $7.0 \%$ & \\
\hline Total variance $(\$)$ & & & 1,680 & & & & 240 & & & & -232 & \\
\hline Total variance $(\%)$ & & & 3.5 & & & & 0.4 & & & & -0.7 & \\
\hline Avg var adj for overall var $(\$)$ & & & 4,882 & & & & 10,424 & & & & 2,152 & \\
\hline Avg var adj for overall var (\%) & & & 10.2 & & & & 17.5 & & & & 6.3 & \\
\hline
\end{tabular}

Source: Ministry of Finance and Economic Development 
28. In order to regularize these variances, the government has passed a number of supplementary appropriations. These appropriations were however passed only after the reallocations had taken place, based on authorization from the MoFED. Given the quantum of reallocation this is a concern, as it appears to pre-empt effective legislative control of appropriation, a key element of the PFM system.

29. This is a significant deterioration from the 2007 PEFA assessment. In 2007, a B was scored on the basis of compositional variance of less than 5 percent in two out of three years, with a maximum variance of 7.8 percent. The assessment in both PEFAs has been undertaken on a functional basis, rather than the preferred administrative or program basis. In the future it will be important to move to at least the program basis.

\section{PI-3. Aggregate revenue outturn compared to original approved budget}

This indicator measures actual domestic revenue collection compared to domestic revenue estimates in the original approved budget.

\begin{tabular}{|l|c|c|}
\hline $\begin{array}{l}\text { 2010 Assessment (scoring method M1) } \\
\text { Dimension: }\end{array}$ & $\begin{array}{c}\text { Score } \\
\mathbf{2 0 1 0}\end{array}$ & $\begin{array}{c}\text { Score } \\
\mathbf{2 0 0 7}\end{array}$ \\
\hline $\begin{array}{l}\text { Actual domestic revenue collection was below 97 percent of budgeted } \\
\text { domestic revenue in no more than one of the last three years }\end{array}$ & $\mathrm{A}$ & $\mathrm{A}$ \\
\hline
\end{tabular}

30. Throughout the period of assessment actual collections exceeded budgeted revenue. In 2007/08 collections exceptionally exceeded original estimates by 10.9 percent. According to the authorities this was due to a number of factors, including the large payments of tax arrears collected in that year, the introduction of advance company tax payments (resulting in a double up of payments from some companies), and an unexpected behavioral response to a reduction in the company tax rate from 22.5 percent to 15 percent. This rationale is consistent with the outcomes from later years, which were within 4 percent of budgeted receipts (Table 8). However, it should be noted that persistent underestimation of revenue receipts can also lead to problems associated with loss of budget credibility and additional spending outside of the annual budget process.

Table 8. Mauritius: Actual Domestic Revenue Compared to Original Budget Estimates

\begin{tabular}{lrrr}
\hline & $\begin{array}{r}\text { 2007-08 } \\
\text { MUR mln }\end{array}$ & $\begin{array}{r}\text { 2008-09 } \\
\text { MUR mln }\end{array}$ & $\begin{array}{r}\text { July-Dec 2009 } \\
\text { MUR mln }\end{array}$ \\
\hline Budget (Original) & $47,566.0$ & $57,558.0$ & $29,156.0$ \\
Actual & $52,767.0$ & $59,436.0$ & $30,000.7$ \\
Difference & $5,201.0$ & $1,878.0$ & 844.7 \\
Percent difference & 10.9 & 3.3 & 2.9 \\
\hline
\end{tabular}

Source: Ministry of Finance and Economic Development 
31. As in many countries, corporate tax revenues have proven to be the most difficult to forecast. A large part of the reason for this is the volatility of profits from offshore companies (with headquarters mainly in India, and subject to the double tax agreement), which makes it difficult to provide a reliable forecast.

32. The Mauritius Revenue Authority (MRA) became operational on July 1, 2006, arising from a merger of three departments organized on the basis of tax-type. Since then a functional organization has been adopted, and significant progress achieved in most line and support functions of tax administration, particularly in the area of taxpayer education. With respect to profit tax, an advance payment schedule was introduced, which smoothed the government's cash-flow by advancing revenue inflows over time.

\section{PI-4. Stock and monitoring of expenditure payment arrears}

This indicator has two dimensions and measures: (i) the level of arrears; and (ii) the availability of data for monitoring the stock of arrears.

\begin{tabular}{|l|c|c|c|c|}
\hline $\begin{array}{l}\text { 2010 Assessment (Scoring method M1) } \\
\text { Dimension: }\end{array}$ & \multicolumn{2}{|c|}{$\begin{array}{c}\text { Score } \\
\mathbf{2 0 1 0}\end{array}$} & \multicolumn{2}{|c|}{$\begin{array}{c}\text { Score } \\
\mathbf{2 0 0 7}\end{array}$} \\
\hline (i) The stock of arrears is less than 2 percent of total expenditure & A & & A & \\
\cline { 1 - 2 } $\begin{array}{l}\text { (ii) Reliable and complete data on the stock of arrears is generated } \\
\text { through routine procedures at least at the end of the fiscal year }\end{array}$ & A & A & A & \\
\cline { 5 - 6 }
\end{tabular}

33. There is no stock of expenditure arrears. All commitments and invoices related to the actual financial year are cleared and paid well ahead of the financial year-end or cancelled; multi-year contracts are handled through annual commitment tranches. The commitment control system supports in-year monitoring of any unpaid transactions. The treasury issues circulars on closing of accounts, these require all ministries and departments to cancel or clear all commitments and invoices prior to the end of the financial year. A three-day window is opened after the year-end to allow payment of a few unpaid invoices (invoices already processed and approved in the TAS, but for which payment has not been effected).

34. In-year control is strict and all payments are effected promptly throughout the year. The accountant-general, director of audit and head of internal control cadre confirmed that no arrears exist at the year-end. The director of audits report for December 31, 2009, only identifies outstanding revenue collection arrears only as an issue.

\section{B. Comprehensiveness and Transparency}

\section{PI-5. Classification of the budget}

This indicator assesses the quality of the classification system used for formulation, execution and reporting of the central government budget. 


\begin{tabular}{|l|c|c|}
\hline $\begin{array}{l}\text { 2010 Assessment (scoring method M1) } \\
\text { Dimension: }\end{array}$ & $\begin{array}{c}\text { Score } \\
\mathbf{2 0 1 0}\end{array}$ & $\begin{array}{c}\text { Score } \\
\mathbf{2 0 0 7}\end{array}$ \\
\hline $\begin{array}{l}\text { The budget formulation and execution system is based on administrative, } \\
\text { economic and program classification using the GFSM2001 standards. } \\
\text { Functional classification can be derived from the program classification. }\end{array}$ & $\mathrm{A}$ & $\mathrm{B}$ \\
\hline
\end{tabular}

35. The classification system used for the budget was changed to GFSM2001 standards in the 2008-09 budget, along with the move to program-based budgeting. The budget classification and chart of accounts include administrative, program, sub-program and economic classification. Functional classification is obtained by mapping from the program and subprogram classification. The budget is appropriated by program.

\section{The transition to program-based budgeting has made it more difficult to identify} expenditure by functional classification. Obtaining a functional classification of expenditure now requires manual mapping from the program expenditure data in the TAS, which is very time consuming. As a result, the published budget documentation no longer includes expenditure according to functional classification. However, the CSO can provide the information upon request (as for the PEFA mission), and does publish functional information in the Digest of Public Finance Statistics, ${ }^{3}$ following the completion of the financial year. The authorities noted that this was a teething issue and they were committed to resolving the mapping issues in the TAS, and a return to publishing functional information in future budget documentation.

\section{PI-6. Comprehensiveness of information included in budget documentation}

This indicator assesses the extent to which budget documentation information is made available for scrutiny and approval by the legislature.

\begin{tabular}{|l|c|c|}
\hline $\begin{array}{l}\text { 2010 Assessment (Scoring method M1) } \\
\text { Dimension: }\end{array}$ & $\begin{array}{c}\text { Score } \\
\mathbf{2 0 1 0}\end{array}$ & $\begin{array}{c}\text { Score } \\
\mathbf{2 0 0 7}\end{array}$ \\
\hline $\begin{array}{l}\text { Recent budget documentation fulfills seven of the nine required } \\
\text { information benchmarks }\end{array}$ & $\mathrm{A}$ & $\mathrm{B}$ \\
\hline
\end{tabular}

37. The budget documentation in Mauritius is relatively comprehensive, with seven out of the required nine benchmarks included in the annual budget documents. The mix of benchmarks included has however changed following the introduction of performance based budgeting as shown in Table 9.

\footnotetext{
${ }^{3}$ Annual Digest of Public Statistics 2008 and 2009, Central Statistical Office, Republic of Mauritius.
} 
Table 9. Mauritius: Comprehensiveness of Budget Documentation

\begin{tabular}{|c|c|c|c|}
\hline No. & Item & Included & Source \\
\hline 1 & $\begin{array}{l}\text { Macroeconomic assumptions, including at least } \\
\text { estimates of aggregate growth, inflation, and } \\
\text { exchange rate }\end{array}$ & No & $\begin{array}{l}\text { The main budget document } \\
\text { does provide information on } \\
\text { GDP and inflation, but not the } \\
\text { exchange rate assumption }\end{array}$ \\
\hline 2 & $\begin{array}{l}\text { Fiscal deficit, defined according to GFS, or other } \\
\text { internationally recognized standard }\end{array}$ & Yes & Main budget document \\
\hline 3 & $\begin{array}{l}\text { Deficit financing, describing anticipated } \\
\text { composition }\end{array}$ & Yes & Main budget document \\
\hline 4 & $\begin{array}{l}\text { Debt stock, including details at least for the } \\
\text { beginning of the current year }\end{array}$ & Yes & Main budget document \\
\hline 5 & $\begin{array}{l}\text { Financial assets, including details at least for the } \\
\text { beginning of the current year in a timely manner }\end{array}$ & Yes & $\begin{array}{l}\text { Appendix } C \text { of main budget } \\
\text { document and in chart of } \\
\text { accounts }\end{array}$ \\
\hline 6 & $\begin{array}{l}\text { Prior year's budget outturn, presented in the } \\
\text { same format as the budget proposal }\end{array}$ & Yes & $\begin{array}{l}\text { Main budget document, but } \\
\text { only the aggregates }\end{array}$ \\
\hline 7 & $\begin{array}{l}\text { Current year's budget (either the revised budget } \\
\text { or the estimated outturn), presented in the same } \\
\text { format as the budget proposal }\end{array}$ & Yes & Main budget document \\
\hline 8 & $\begin{array}{l}\text { Summarized budget data for both revenue and } \\
\text { expenditure according to the main heads of the } \\
\text { classifications used, including data for the } \\
\text { current and previous year }\end{array}$ & Yes & $\begin{array}{l}\text { Main budget document } \\
\text { provides the information on an } \\
\text { economic and program } \\
\text { classification }\end{array}$ \\
\hline 9 & $\begin{array}{l}\text { Explanation of budget implications of new policy } \\
\text { initiatives, with estimates of the budgetary impact } \\
\text { of all major revenue policy changes and/or some } \\
\text { major changes to expenditure programs }\end{array}$ & No & $\begin{array}{l}\text { The budget speech outlines } \\
\text { new initiatives, but does not } \\
\text { provide financial implications }\end{array}$ \\
\hline
\end{tabular}

Source: Ministry of Finance and Economic Development

38. The macroeconomic assumptions are annexed to budget documents, except for the exchange rate assumption. This is relatively simple to adjust for future documents, and if included will further inform the basis of the balance of payments, inflation and customs duty projections all of which are dependent on the exchange rate assumption. Most of the information in the budget documents is provided in tabular format, with limited analysis or discussion of the programs, the macroeconomic projections, or the revenue and expenditure aggregates.

\section{The budget documents provide GFSM2001 based analysis of the fiscal deficit,} debt financing, debt stock and financial assets and contain summaries of revenue and expenditure according to the main classification heads. However, since introducing program-based budgeting, the government has stopped providing summary expenditure data by functional classification. This information is however made public in the publication of the Digest of Public Finance Statistics, ten months after the end of the financial year. Including this information would improve comparability with previous budgets as well as with other countries. 
40. The prior year's budget data is presented at the aggregate level in the main budget document. Although this does not meet the strict requirement for this indicator, the required detailed analysis of prior year's budget outturn, is included in the prior year financial statements which are presented at the same time as the budget. The revised current year's budget is presented in the same format as the budget proposal in the main budget document.

\section{There is no explanation of the financial implications of new policy initiatives} included in the budget documentation. While the Finance Minister's budget speech provides an exhaustive explanation of new initiatives, there is little information provided on the cost to the budget, either in the budget year or over the medium term. As a result, it is difficult to determine how large and/or important each new initiative is and their overall impact on the budget.

\section{PI-7. Extent of unreported government operations}

This indicator has two dimensions measuring: (i) the level of unreported extra-budgetary expenditure (excluding donor-funded projects); and (ii) the information on donor-funded projects included in fiscal reports.

\begin{tabular}{|c|c|c|c|c|}
\hline $\begin{array}{l}\text { 2010 Assessment (Scoring method M1) } \\
\text { Dimensions: }\end{array}$ & \multicolumn{2}{|c|}{$\begin{array}{l}\text { Score } \\
2010\end{array}$} & \multicolumn{2}{|c|}{$\begin{array}{c}\text { Score } \\
2007\end{array}$} \\
\hline $\begin{array}{l}\text { (i) The level of unreported extra-budgetary expenditure (other } \\
\text { than donor-funded projects) constitutes more than } 10 \text { percent of total } \\
\text { expenditure }\end{array}$ & D & $\mathrm{D}+$ & $\mathrm{D}$ & $\mathrm{D}+$ \\
\hline $\begin{array}{l}\text { (ii) Complete income/expenditure information for } 90 \text { percent of its } \\
\text { donor funded projects are included in fiscal reports }\end{array}$ & $\mathrm{A}$ & & A & \\
\hline
\end{tabular}

\section{Central government gross expenditure is only partially reflected in the annual} budget estimates and in in-year budget execution statements. However full disclosure is made in the year-end financial statements of central budgetary government and in the individual financial statements EBUs. In addition, a full summary analysis is provided in the annual published Digest of Public Finance Statistics. Annual program budget estimates for the period 2007/08 to 2009 however record transfers, by program, to EBUs. In the three periods 2007/08, 2008/09 and 2009 EBUs comprised over 110 agencies, special funds and statutory funds. These transfers do not fully reflect gross expenditure as some of the EBUs have their own revenue sources, from which additional expenditure can be financed, and which are not reported.

\section{In 2008/09 EBUs reported over MUR10 billion of surplus, according to the Digest} of Public Finance Statistics, in a surplus of revenues. The 2011 budget estimates report that significant savings also existed on a number of key EBU accounts in the period July-December 2009. These surplus funds were unspent at the year-end and were invested in domestic securities. Ex ante, the budget documentation for FY2009, did not fully disclose the nature of government operations referring only to transfers to EBUs in program estimates, equivalent to MUR21.9 
billion. It is noted that ex ante disclosures (including the budgets for seven material special funds) were made, in the 2010 budget document, which provides greater levels of disclosure for the key EBUs.

44. Complete income and expenditure information for donor-funded projects are included in fiscal reports and through the period represent less than 10 percent of total central government expenditure. Project specific donor financing, excluding general budget support in the three fiscal periods 2007/08, 2008/09 and 2009 amounted to MUR0.4 billion, MUR1.5 billion and MUR0.9 billion respectively. At 0.6, 2.2 and 2.3 percent respectively, these represent substantially less than 10 percent of total central government expenditure.

\section{PI-8. Transparency of intergovernmental fiscal relations}

This indicator has three dimensions that measure the: (i) transparency and objectivity in the horizontal allocation between subnational governments; (ii) timeliness of reliable information to subnational governments; and (iii) extent of consolidation of fiscal data for general government according to sectoral categories.

\begin{tabular}{|c|c|c|c|c|}
\hline $\begin{array}{l}\text { 2010 Assessment (scoring method M2) } \\
\text { Dimensions: }\end{array}$ & & & & \\
\hline $\begin{array}{l}\text { (i) No part of the horizontal allocation of transfers from central government is } \\
\text { determined by transparent and rules based systems }\end{array}$ & $\bar{D}$ & \multirow{3}{*}{ B } & $\mathrm{A}$ & \multirow{3}{*}{$\mathrm{A}$} \\
\hline $\begin{array}{l}\text { (ii) Reliable information is provided on allocations ahead of completing } \\
\text { budget proposals and in-time significant budget changes }\end{array}$ & $B$ & & $\mathrm{~A}$ & \\
\hline $\begin{array}{l}\text { (iii) Fiscal information for (ex ante and ex post) that is consistent with central } \\
\text { government is collected for } 90 \text { percent of subnational government and } \\
\text { consolidated into annual reports within ten months of the end of the fiscal } \\
\text { year }\end{array}$ & $\mathrm{A}$ & & $\mathrm{A}$ & \\
\hline
\end{tabular}

45. Horizontal allocations to local authorities have not been based on any objective rulebased criteria. Subnational government consists of five municipalities, four district councils and one regional government for Rodrigues. The municipal and district councils received full year grants from central government, which totaled MUR1.7 billion in 2008-09 and covered 66 percent of local authority expenditure. These grants are not disaggregated. The last half-year government grant of R1.3 billion for July-December 2009 covered 68 percent of expenditure. At one time the grants were based on a specific formula, but since 1998-99 they have been incrementally increased, on an annual basis, without reference to the previous formula components. With the substantial change in the socio-economic structure of local governments in Mauritius the old formulae is no longer representative. It is noted that the previous 2007 rating did not reflect the absence of a rules based framework.

46. The grant for the island of Rodrigues is negotiated annually as part of the budget process, based on a formal budget submission. This reflects the greater autonomous status including its own elected assembly and several devolved government functions. 
47. Local authorities are provided reliable information on budget allocations before the start of their budgeting process. For FY2007-08 and FY2008-09, local authorities received information on grant allocations approximately one month (May) before the start of the new budget year, which the MoFED acknowledges leaves limited time for preparation of detailed budgets; however, according to the authorities, does allow sufficient time for incorporation of any significant changes. The grant information for the period July to December 2009 was subject to further delay, due to the change in financial year and eventually made available in July 2009. This delay was a temporary transitional issue and has therefore been ignored in this assessment.

\section{Subnational governments report monthly and produce annual financial statements.} Consolidated central and local government fiscal information by economic category is fully reported in the Digest of Public Finance Statistics within ten months of the end of the financial year. The July 2010 report of the director of audit confirms that the financial statements, for all subnational governments for 2007-08, were submitted and, with the exception of one council (Rose Hill), are certified within ten months of the year-end. The Digest of Public Finance Statistics covering 2007-08 was published in May 2009, and for the 18 months, July 2008 to December 2009, in October 2010.

\section{PI-9. Oversight of aggregate fiscal risk from other public sector entities}

This indicator has two dimensions and assesses the: (i) extent of central government monitoring of EBUs and public enterprises; and (ii) extent of central government monitoring of subnational governments' fiscal position.

\begin{tabular}{|l|c|c|c|c|}
\hline $\begin{array}{l}\text { 2010 Assessment (scoring method M1) } \\
\text { Dimensions: }\end{array}$ & \multicolumn{2}{|c|}{$\begin{array}{c}\text { Score } \\
\mathbf{2 0 1 0}\end{array}$} & \multicolumn{2}{c|}{$\begin{array}{c}\text { Score } \\
\mathbf{2 0 0 7}\end{array}$} \\
\hline $\begin{array}{l}\text { (i) Most major EBUs and Public Enterprises submit annul fiscal } \\
\text { reports to central government but a consolidated overview is not } \\
\text { prepared }\end{array}$ & C & B & \\
\cline { 1 - 2 } $\begin{array}{l}\text { (ii) Subnational government cannot generate fiscal liabilities for } \\
\text { central government }\end{array}$ & A & & A & \\
\cline { 1 - 3 }
\end{tabular}

49. Government analyzes various aspects of fiscal risk in formulating the budget, and also monitors some of these risks during budget execution. The fiscal risk analysis covers public debt, loan guarantees and the operations of some key EBUs and Public Enterprises, periodic review of pension liabilities and continuous review of implicit guarantees to financial institutions. Risk assessments are not however consolidated systematically or consolidated into a set of formal reports. The director of audit notes a number of risks that suggests the need for a more formalized assessment process, including: (i) delayed submission of a number of EBU financial statements (18) for statutory bodies in 2008-09 creating uncertainty on performance; (ii) very short average maturity of the domestic debt profile as at the end of June 2009, 51 percent being due within the 18-month period to December 2010; (iii) increasing public debt levels (close to the 60 percent fiscal rule limit) and debt servicing (averaging 20 percent of total 
expenditure) over the last three years; and (iv) significantly increasing arrears of revenue yearon-year.

50. Subnational governments are required to maintain a balanced budget and cannot enter into debt agreements, without the explicit authority of the ministry of local government and the MoFED. Subnational governments submit in-year accounts to facilitate in-year monitoring by MoFED on a monthly basis, and have not engaged in any borrowing.

\section{PI-10. Public access to key fiscal information}

This indicator assesses transparency by ascertaining the accessibility of fiscal information to the public against a number of information benchmarks.

\begin{tabular}{|l|c|c|}
\hline $\begin{array}{l}\text { 2010 Assessment (Scoring method M1) } \\
\text { Dimension: }\end{array}$ & $\begin{array}{c}\text { Score } \\
\mathbf{2 0 1 0}\end{array}$ & $\begin{array}{c}\text { Score } \\
\mathbf{2 0 0 7}\end{array}$ \\
\hline $\begin{array}{l}\text { Recent budget documentation fulfills three of the six information } \\
\text { benchmarks as shown in Table 10 }\end{array}$ & $\mathrm{B}$ & $\mathrm{A}$ \\
\hline
\end{tabular}

51. Annual budget documents in Mauritius are freely available to the public and in a timely fashion. All budget documents are placed on the MoFED website immediately upon the submission of the budget to parliament and published documents are available. Monthly outturn reports were not made publicly available over 2008-09 and July-December 2009, although the ministry of finance resumed posting them as of 2010 .

Table 10. Mauritius: Public Access to Fiscal Information

\begin{tabular}{llcl}
\hline No. & \multicolumn{1}{c}{ Item } & Available & \multicolumn{1}{c}{ Source } \\
\hline 1 & Annual budget documentation & Yes & MoFED website \\
2 & In-year execution reports & No & MoFED website \\
3 & $\begin{array}{l}\text { Year-end financial statements six } \\
\text { months after end of fiscal year }\end{array}$ & Yes & The treasury website \\
4 & External audit reports & Yes & National audit office website \\
5 & Contract awards & No & Some information is provided on \\
& various ministry websites
\end{tabular}

Source: Ministry of Finance and Economic Development

52. Audited year-end financial statements are made public well within the six months from completion of audit. In recent cases they have prepared the year-end reports within six months of the end of the financial year, and then been audited within six months. The audited July-December 2009 year-end accounts were publically available by May 2010. External audit reports are placed on the National Audit Office website within six months of completion. 
53. Contract awards are also published on executing agency websites, but there is no aggregate statistical evidence, the individual award information is also deleted from the website after 30 days. There are clear requirements under the legal and regulatory framework on the information on contract awards to be published. These include bidding documents, independent review panel reports and information on awards to bidders within seven days of the award of contract (100 percent). While individual executing agencies may comply with these requirements, it is not possible due to limited aggregate statistics and monitoring, to assess the overall situation.

54. Information on resources available to primary resource units are not published in the budget documents. From discussions with authorities, it does not appear that this information is readily obtainable from individual departments.

\section{Policy-based Budgeting}

\section{PI-11. Orderliness and participation in the annual budget process}

This indicator has three dimensions and assesses the: (i) existence and adherence to a fixed budget calendar; (ii) existence of quality of guidance on the preparation of budget submissions; and (iii) timely budget approval by the legislature.

\begin{tabular}{|c|c|c|c|c|}
\hline $\begin{array}{l}2010 \text { Assessment (scoring method M2) } \\
\text { Dimensions: }\end{array}$ & \multicolumn{2}{|c|}{$\begin{array}{l}\text { Score } \\
2010\end{array}$} & \multicolumn{2}{|c|}{$\begin{array}{l}\text { Score } \\
2007\end{array}$} \\
\hline $\begin{array}{l}\text { (i) An annual budget calendar exists but substantial delays are } \\
\text { experienced in its implementation. The calendar allows } \\
\text { insufficient time for some ministries and agencies to meaningfully } \\
\text { complete their budget estimates }\end{array}$ & $\mathrm{C}$ & \multirow{3}{*}{$\mathrm{B}+$} & B & \multirow{3}{*}{ B } \\
\hline $\begin{array}{l}\text { (ii) A comprehensive and clear budget circular is issued to } \\
\text { ministries and agencies which reflects approved cabinet ceilings } \\
\text { prior to distribution to line ministries and agencies }\end{array}$ & $\mathrm{A}$ & & $\mathrm{C}$ & \\
\hline $\begin{array}{l}\text { (iii) The legislature has during the last three years approved the } \\
\text { budget before the start of the year }\end{array}$ & $\mathrm{A}$ & & $\mathrm{A}$ & \\
\hline
\end{tabular}

55. A clear annual budget calendar exists and is largely adhered to, although it does not provide sufficient time for line ministries to prepare complete budget submissions. The issuance dates of the budget circular and time required for line ministries to complete the submissions over the budgets included in the assessment period were as shown in Table 11.

Table 11. Mauritius: Budget Submission Dates

\begin{tabular}{lccc}
\hline Budget & Date of Issue & Submission Date & $\begin{array}{c}\text { Weeks } \\
\text { Provided }\end{array}$ \\
\hline 2007-08 & Mar 6, 2007 & Mar 30, 2007 & 3.4 \\
$2008-09$ & Feb 21, 2008 & Mar 18, 2008 & 3.7 \\
Jul-Dec 2009 & Nov 29, 2008 & Jan 31, 2009 & 9.0 \\
2010 & Aug 25, 2009 & Sep 18, 2009 & 3.4 \\
\hline
\end{tabular}

Source: Ministry of Finance and Economic Development 
56. There is no fiscal policy paper produced prior to the budget circular and a threeto four-week period does not provide enough time for agencies to prepare meaningful budget submissions. Linkages between macroeconomic projections, fiscal strategy, ministry level strategic plans and the budget process remain limited. A number of major departments noted that they struggle to meet the deadline, and the quality of some of the submissions related to capital projects is inadequate as a result of the need to meet budget deadlines.

57. The budget circular provides clear guidance to line ministries over the budget process, timing and information required in submissions. The circular provides three-year budget ceilings to each ministry, by program-although some substitution between programs within the overall ceiling is permissible. The ceilings are approved by cabinet before the circular is issued. The setting of expenditure ceilings for the budget circular however, receives limited policy inputs from budgetary bodies, leading to relatively weak policy rationales behind the ceilings, and weak acceptance of the ceilings by ministry policy makers. This is evidenced by the subsequent submission of line ministry bids, which in some cases exceed the ceiling by 15-20 percent.

58. The legislature has also approved the budget before the start of the fiscal year in each of three fiscal periods under consideration.

59. The budget includes forecasts of the main fiscal aggregates over three years on a rolling basis. The program estimates are also provided on a rolling three-year basis in the budget documents. However, there is no clear link between the outer years and subsequent budgets estimates. This reduces the importance of the outer-year estimates to the budget process. It also undertakes an annual debt sustainability analysis.

60. Costed sector strategies exist for only a small portion of the budget. The IT industry and SME environment and agriculture sectors, together representing 8 percent of the budget are the only sectors with fully costed strategies. Further work is being done on this measure, with the education and health expecting to complete their strategies by mid-2011, and strategies in other sectors at various stages of preparation.

\section{PI-12. Multiyear perspective in fiscal planning, expenditure policy, and budgeting}

This indicator has four dimensions and assesses the: (i) preparation of multi-year fiscal forecasts; (ii) scope and frequency of debt sustainability analysis; (iii) existence of sector strategies; and (iv) linkages between capital and recurrent estimates.

\begin{tabular}{|c|c|c|c|c|}
\hline $\begin{array}{l}2010 \text { Assessment (scoring method M2) } \\
\text { Dimensions: }\end{array}$ & \multicolumn{2}{|c|}{$\begin{array}{l}\text { Score } \\
2010\end{array}$} & \multicolumn{2}{|c|}{$\begin{array}{l}\text { Score } \\
2007\end{array}$} \\
\hline $\begin{array}{l}\text { (i) Forecasts of fiscal aggregates are prepared for at least two years on } \\
\text { a rolling basis }\end{array}$ & $\mathrm{C}$ & \multirow{4}{*}{$\mathrm{C}+$} & $\mathrm{D}$ & \multirow{4}{*}{$\mathrm{D}+$} \\
\hline (ii) A DSA for external and domestic debt is undertaken annually & A & & B & \\
\hline iii) Costed sector strategies represent less than 25 percent of total & $\mathrm{C}$ & & $\mathrm{D}$ & \\
\hline $\begin{array}{l}\text { (iv) Budgeting for investment and recurrent expenditure are } \\
\text { separate processes with no sharing of recurrent costs of capital }\end{array}$ & $\mathrm{D}$ & & $\mathrm{D}$ & \\
\hline
\end{tabular}


61. There are only very limited links between investment and recurrent expenditures in the medium-term budget estimates. Recurrent costs are determined at the early stages of capital project assessments, and ministries are requested to include these in their capital project budget submissions. While some attempt is made to recognize significant recurrent cost implications in the budget, overall recurrent expenditure implications are not fully captured in sector strategies or in budget submissions.

\section{Predictability and Control in Budget Execution}

\section{PI-13 Transparency of taxpayer obligations and liabilities}

This has three dimensions which assess the: (i) clarity and comprehensiveness of tax liabilities; (ii) taxpayer access to information on tax liabilities; administrative procedures; and (iii) existence and functioning of a tax appeals mechanism.

\begin{tabular}{|c|c|c|c|c|}
\hline $\begin{array}{l}\text { 2010 Assessment (scoring method M2) } \\
\text { Dimensions: }\end{array}$ & \multicolumn{2}{|c|}{$\begin{array}{l}\text { Score } \\
2010\end{array}$} & \multicolumn{2}{|c|}{$\begin{array}{l}\text { Score } \\
2007\end{array}$} \\
\hline $\begin{array}{l}\text { (i) Legislation and procedures for all major taxes are comprehensive and } \\
\text { clear, with strictly limited discretionary powers of the government entities } \\
\text { involved }\end{array}$ & $\mathrm{A}$ & \multirow{3}{*}{$\mathrm{B}^{+}$} & B & \multirow{3}{*}{ B } \\
\hline $\begin{array}{l}\text { (ii) Taxpayers have easy access to comprehensive, user friendly and up-to- } \\
\text { date information on tax liabilities and administrative procedures for all } \\
\text { major taxes and the RA supplements this with active taxpayer education } \\
\text { campaigns }\end{array}$ & $\mathrm{A}$ & & B & \\
\hline $\begin{array}{l}\text { (iii) A tax appeals system for administrative procedures has been establis } \\
\text { but needs substantial redesign to be fair, transparent and effective }\end{array}$ & $\mathrm{C}$ & & $\mathrm{C}$ & \\
\hline
\end{tabular}

62. Mauritius' tax laws and regulations are overall of good quality. A significant number of tax rulings (38 on VAT, 105 on other taxes) contain MRA's interpretation of the law upon which taxpayers can rely. These have been issued and made available via the MRA website. Seven statements of practice have also been published. Existing tax concessions (also known as tax incentives) have recently been removed or included in the various tax laws. All of these developments promote transparency and limit the discretion of the authorities. In the period under review, income tax was also simplified significantly; deductions were eliminated, whilst at the same time rates were reduced significantly, from a top rate of 30 percent prior to 2006-07, 22.5 percent in 2006-07, to 15 percent in 2007-08. Agreements for the avoidance of double taxation have been negotiated with 36 countries including regional partners and major global investors, ten treaties are also being negotiated.

63. Mauritius' tax laws and regulations are readily accessible via the MRA's website, which is updated frequently throughout the year. Multiple education sessions or awareness campaigns are organized each year by the Taxpayer Education and Communication Department. These communications are however in English only, and not in French or Creole, the primary language of preference for most of the population. MRA's taxpayer charter from December 2006 has two versions, an accurate written presentation (in Chapter 4 of MRA's last two annual 
reports) that mentions taxpayer obligations and a graphical website presentation which has some limitations.

64. The formal appeals mechanism has some serious limitations which suggest the need for a substantial redesign to ensure fairness, transparency and effectiveness. Mauritius has had a Tax Appeals Tribunal since 1984; in 2003 this was replaced by the current Assessment Review Committee (ARC), a non-judicial body. The provisions governing the ARC have been included in the MRA Act, although the ARC is and should be independent from MRA; potential investors might be misguided in this respect, by the fact that the provisions concerning the ARC were included in the Revenue Authority Act. Furthermore the scope of the ARC's activities, in conformity with its name is limited to assessments.

65. Taxpayers have no right to appeal against rulings. A taxpayer may adopt a position different from an MRA ruling, and then object and appeal against an assessment in line with the said ruling, but this is risky, and the current situation may lead to potential investments not being realized. Taxpayers are entitled to appeal against decisions by the ARC to the Supreme Court, but only with respect to matters of law, not matters of fact, this limitation is a serious one. MRA currently wins over 80 percent of the cases.

66. In addition, vacancies of the judicial officer positions at ARC have caused serious delays in hearings and the determination of cases. Since April 2009 it has had only one vicechairperson, and since early 2010 none. The MRA Act (Article 20(3) (a)(i)) requires that an ARC panel shall endeavor to give its decision on the representations no later than eight weeks from the start of the hearing. With respect to cases involving the Registrar-General this is generally possible, but most cases involving MRA currently take months, and sometimes up to two years. Detailed tables, shown in Table A3 of Annex III, which do not cover cases involving the Registrar-General or those concerning Customs and Excise, show that the situation deteriorated in 2008-09, with the number of pending cases rising by 81 percent, and the disputed amount rising by (at least) 51 percent. It will take more than three years to clear all cases currently pending before the ARC (ignoring any new cases lodged). In terms of numbers of cases and amounts disputed, this stage of litigation was fairly stable between 2006-07 and 2008-09, but the quality of reporting on the case statistics in MRAs annual reports needs to be improved.

\section{PI-14. Effectiveness of measures for taxpayer registration and assessment}

This indicator has three dimensions which assess the: (i) controls in the taxpayer registration system; (ii) effectiveness of penalties for non-compliance with registration and declaration obligations; and (iii) planning and monitoring of tax audit and fraud investigation programs. 


\begin{tabular}{|c|c|c|c|c|}
\hline $\begin{array}{l}2010 \text { Assessment (scoring method M2) } \\
\text { Dimensions: }\end{array}$ & \multicolumn{2}{|c|}{$\begin{array}{c}\text { Score } \\
2010\end{array}$} & \multicolumn{2}{|c|}{$\begin{array}{l}\text { Score } \\
2007\end{array}$} \\
\hline $\begin{array}{l}\text { (i) Taxpayers are registered in a complete database system with } \\
\text { some linkages to other relevant government registration systems } \\
\text { and financial sector regulators }\end{array}$ & B & \multirow{3}{*}{$\mathrm{B}+$} & A & \multirow{3}{*}{ B +} \\
\hline $\begin{array}{l}\text { (ii) Penalties for non-compliance exist for most relevant areas, but } \\
\text { are not always effective due to insufficient scale and /or } \\
\text { inconsistent administration }\end{array}$ & B & & B & \\
\hline $\begin{array}{l}\text { (iii) Tax audits and fraud investigations are managed and reported } \\
\text { on according to a documented audit plan, with clear risk } \\
\text { assessment criteria for all major taxes that apply self-assessment }\end{array}$ & $\mathrm{A}$ & & B & \\
\hline
\end{tabular}

\section{MRA maintains a database of registered taxpayers, including the central} business database of the Board of Investment to which it has direct access. This covers data on purchasers of real estate and vehicles; databases of all licenses issued by local authorities, including construction licenses; and information held by its own field officers responsible for tracking unregistered businesses. In recent annual reports ${ }^{4} \mathrm{MRA}$ presents registration of taxpayers as shown in Table 12. This shows the impact of recent increases in the level of tax exempt thresholds and a general rise in all other registrations in line with the general progress in MRA's operations. However MRA's Corporate Plan 2008-10 reported that compliance by professionals like architects and doctors was a matter of concern: only 65 percent and 69 percent respectively were filing returns, and only 48 percent and 59 percent were paying tax. During the missions various sources from the private sector indicated that this remains the case. It appears this information was not apparent during the first PEFA assessment of 2007. The same MRA Corporate Plan announces measures to address the situation, and the Fiscal Investigations Department has been set up inter alia with the objective to focus on professionals, but an evaluation of the effectiveness of those measures is not yet available.

Table 12. Mauritius: Taxpayer Registration

\begin{tabular}{|l|r|r|r|r|r|}
\hline & \multicolumn{1}{|c|}{$\mathbf{2 0 0 6 - 0 7}$} & \multicolumn{2}{|c|}{$2007-08$} & \multicolumn{2}{|c|}{$2008-09$} \\
\hline Category & & Number & $\begin{array}{r}\text { Growth Rate } \\
\text { (percent) }\end{array}$ & Number & $\begin{array}{r}\text { Growth Rate } \\
\text { (percent) }\end{array}$ \\
\hline Companies & & & 21.5 & 51,593 & 7.7 \\
Individuals-emoluments only & 39,431 & 47,896 & -46.1 & 102,199 & -35.2 \\
Individuals-self-employed/mixed & 292,468 & 157,601 & 20.3 & 65,441 & 10.5 \\
Income & 49,209 & 59,214 & & & \\
Societies & & & & 4,496 & 6.1 \\
Successions & 3,856 & 4,239 & 9.9 & 1,919 & 5.8 \\
Total & 1,688 & 1,813 & 7.4 & -16.7 \\
\hline
\end{tabular}

Source: Ministry of Finance and Economic Development

\footnotetext{
${ }^{4}$ MRA Annual Report 2007/08, page 43, and MRA Annual Report 2008/09, page 37.
} 
68. The design of the regime of tax penalties deviates from international standards in a number of respects..$^{5}$ The Income Tax Act provides for "a penalty not exceeding 50 percent," which gives MRA considerable discretion and MRA's criteria to determine the penalty rate are not communicated to the public. First, MRA has guidelines for determining penalties which partly depend on the taxpayer's agreement regarding the assessment raised, which might boil down to punishing the taxpayer for holding certain legal opinions or for defending them in court. Instead, it is international best practice to let penalties (expressed as a percentage of the amount of tax not paid) depend explicitly on the degree of culpability of the taxpayer. Secondly, some maximum penalties are fixed amounts which have been eroded by inflation over time. Some mechanism should be in place to ensure regular adjustments are made. Such fixed rate penalties should either be regularly subjected to review, or have an automatic adjustor built into legislation. Thirdly, the phrase "on conviction," instead of "on administrative conviction," suggests that MRA is always in need of the intervention of a penal court, not only for crimes but even for routine offences perpetrated without reasonable cause or due to gross neglect, for which, by international standards, the tax administration, should be the competent institution.

\section{The information in MRA's Corporate Plan 2008-10 on compliance by selected} groups, including professionals suggests that the penalties are not effective to ensure taxpayers compliance. Any revaluation of real estate by the authorities with respect to the Registration Duty on Transfer of Immovable Property automatically triggers a penalty of 100 percent, irrespective of the degree of culpability of the taxpayer, who in all circumstances may arrive at a different estimate of fair market value than the authorities given that valuation is not an exact science. Furthermore, there are concerns about MRA not enforcing the provisions (mainly clause 22) in the Income Tax Regulations (1996) concerning the obligations of employers and other withholders of taxes deducted at source to submit documentation matching their payments.

\section{Since the inception of MRA in July 2006, audits of the various taxes have been} integrated and guided by risk criteria which are regularly evaluated. The Large Taxpayer Department attempts to audit at least 25 percent of its 800 to 900 taxpayers, so that on average each taxpayer is audited every four years. In 2007-08 this target was not met (11.1 percent of all LTD taxpayers), but in 2008-09 it was exceeded (Table A4 in Annex III). In spite of the sharply increased number of audits (45 percent up), the total amount raised by additional assessments went down in 2008-09. This is related to the recent changes in tax policy in 2007-08, characterized by a reduction of tax rates accompanied by simplification, in particular a reduction of the number of allowable deductions. This has led to a reduced need to impose amended assessments, and enabled the audit staff to increase productivity in terms of the number of desk

\footnotetext{
${ }^{5}$ See the last half of Richard K. Gordon: "Law of Tax Administration and Procedure", Chapter 4 in V. Thuronyi (Ed.): Tax Law Design and Drafting, Vol. 1, IMF, Washington DC, 1996, available via www.imf.org/external/pubs/nft/1998/tlaw/eng.
} 
and field audits. The amended assessments for 2007-08 were exceptionally high due to the Voluntary Disclosure Incentive Scheme that was in force in that year.

\section{Another yardstick for productivity, amount per amended assessment, went also}

sharply up by 56 percent. Other underlying factors in the increases in productivity were the fact that field auditors were provided with laptop computers, as well as continued efforts in capacity building of audit staff inside Mauritius or internationally. Like taxpayer audit, the tax investigations function is covered by MRA's annual plan. The annual plan defines the sectors which the Fiscal Investigations Department will focus on. During the period reviewed progress has been made in terms of numbers of investigations completed, and tax yield resulting from investigations.

\section{PI-15. Effectiveness in collection of tax payments}

This indicator has three dimensions which assess the: (i) collection ratio for gross tax arrears; (ii) effectiveness of transfer of tax collections to the treasury by the revenue administration; and (iii) frequency of complete accounts reconciliation between tax assessments, collections, arrears records, and receipts by the treasury.

\begin{tabular}{|c|c|c|c|c|}
\hline 2010 Assessment (scoring method M1) & \multicolumn{2}{|c|}{ Score 2010} & \multicolumn{2}{|c|}{ Score 2007} \\
\hline $\begin{array}{l}\text { (i) The average debt collection ration in the two most recent fiscal } \\
\text { years was } 60-75 \text { percent and the total amount of tax arrears is } \\
\text { significant }\end{array}$ & $\mathrm{C}$ & \multirow{3}{*}{$\mathrm{C}+$} & $\mathrm{D}$ & \multirow{3}{*}{$\mathrm{D}+$} \\
\hline $\begin{array}{l}\text { (ii) All tax revenue is paid directly into accounts controlled by the } \\
\text { treasury or transfers to the treasury are made daily }\end{array}$ & A & & A & \\
\hline $\begin{array}{l}\text { (iii) Complete reconciliation of tax assessments, collections, arrears } \\
\text { and transfers to treasury takes place at least monthly within one } \\
\text { month of the end of the month }\end{array}$ & A & & $\mathrm{A}$ & \\
\hline
\end{tabular}

\section{Effective collection efforts appear to be undermined by problems with writing-off} tax liabilities that cannot be collected. These results in a lower ratio of tax debt collections to tax debts than would have otherwise been the case. This prevents Mauritius from scoring higher on this dimension. There has been recent progress since the MRA Act was amended in 2009 so that the approval of the minister of finance is no longer required. Instead all write-offs are to be approved by the MRA Board after comments from the director of audit. The Income Tax Act says that if a taxpayer objects to an assessment, he shall pay 30 percent of the amount of income tax and not of the disputed amount of tax. If the taxpayer fails to do so, within about a month, the law determines that the objection has lapsed; but the ARC follows the interpretation that this is unconstitutional, and that it has the right to look into the matter if the taxpayer was not able to pay up the amount in time. 
73. MRA's Annual Report 2008-09 reports significant amounts of disputed taxes and collectible debt arrears equivalent to 4.1 percent and 4.7 percent of total revenue, respectively. By June 30, 2008, the disputed amounts equaled to MUR2.0 billion. Collectible debt, in arrears, is of the same order of magnitude: MUR1.9 bn. By June 30, 2009, (Table A5). The MRA Annual Reports do not specify arrears concerning Customs Duties and Excises, and do not report debt write-offs. MRA provided an "age analysis of debt," showing that by June 30, $2007,64.1$ percent of the outstanding amount was overdue by two years or more, and that 8.0 percent was overdue between one and two years. The Tax Arrears Payment Incentive Scheme from 2007-08 reduced the share of debts outstanding for more than two years to 44 percent, but this effect may have been temporary. Figures for the most recent Financial Year (July 2009December 2009) are not yet available.

74. The frequency of transfers of revenue collections to the Treasury Account is at least once per day. The main collection points are MRA head office, Customs House, and (of subordinate importance) Customs Airport. Customs House sweeps their account twice per day. MRA H/Q sweep every morning, but when there is a peak period (around the annual filing deadline) they also sweep twice per day.

75. Reconciliation takes places on a monthly basis. This frequency is high with use being made of the TAS. However, the follow-up to the reconciliation reports deserves attention.

\section{PI-16. Predictability in the availability of funds for commitment of expenditure}

This indicator has three dimensions that assess the: (i) extent to which cash flows are forecast and monitored; (ii) reliability and horizon of periodic in-year information on ceilings or expenditure commitment; and (iii) frequency and transparency of adjustments to budget allocations above the level of management of the ministries.

\begin{tabular}{|l|c|c|c|c|}
\hline 2010 Assessment (Scoring method M1) & \multicolumn{2}{|c|}{$\begin{array}{c}\text { Score } \\
\text { Dimensions: }\end{array}$} & \multicolumn{2}{|c|}{$\begin{array}{c}\text { Score } \\
\mathbf{2 0 0 7}\end{array}$} \\
\hline $\begin{array}{l}\text { (i) Cash flows are prepared for the fiscal year and updated monthly } \\
\text { reflecting actual cash inflows and out-flows }\end{array}$ & A & & A & \\
\cline { 1 - 1 } $\begin{array}{l}\text { (ii) MDAs are able to plan and commit expenditure at least six } \\
\text { months in advance in accordance with budgeted appropriations }\end{array}$ & A & C + & A & A \\
\cline { 1 - 1 } $\begin{array}{l}\text { (iii) Significant in-year adjustments are frequent but undertaken with } \\
\text { some transparency }\end{array}$ & C & & A & \\
\hline
\end{tabular}

76. Cash flow forecasts are prepared upfront for the fiscal year and are entered into the TAS. The cash flow forecasts, which are updated monthly, are monitored daily by the treasury against actual daily cash inflows and outflows. The cash flow forecasts reflect revenue collection profiles and spending plan requirements (based on the budgets), and are used in the determination of financing requirements. Recording and management of cash balances and debt are made on a daily, monthly, and quarterly basis. 
77. Commitments ceilings in the form of warrants (authority to spend) are released to ministries and departments by the accountant-general at the beginning of the year (after the approval of the budget). Funds are released when required as Treasury effects payments for most of the ministries and departments through the single treasury account. Therefore, ministries, departments and agencies (MDAs) are able to plan and commit expenditure for up to a year in advance.

78. However, significant in-year budget adjustments take place frequently during the year, approved by the MoFED. The reallocations are consolidated once or twice a year into supplementary budgets and are presented to Parliament for approval of extra supplementary appropriation. The supplementary budgets are made publicly available on MoFED website. For the three periods, absolute variance between functional classification composition was 13.6 percent (2007-08), 17.9 percent (2008-09), 7 percent for July to December 2009 (refer to PI-2) with the main allocation relating to reallocation from capital budget to recurrent budget. This level of reallocation is therefore rated a $\mathrm{C}$. This compares to previous years where, while frequency of reallocations was relatively high, the amount of reallocations were low and hence the score was A.

\section{PI-17. Recording and management of cash balances, debt, and guarantees}

This indicator has three dimensions which assess the: (i) quality of debt data recording and reporting; (ii) extent of consolidation of the government's cash balances; and (iii) systems for contracting loans and issuance of guarantees.

\begin{tabular}{|c|c|c|c|c|}
\hline $\begin{array}{l}2010 \text { Assessment (scoring method M2) } \\
\text { Dimensions: }\end{array}$ & \multicolumn{2}{|c|}{$\begin{array}{l}\text { Score } \\
2010\end{array}$} & \multicolumn{2}{|c|}{$\begin{array}{l}\text { Score } \\
2007\end{array}$} \\
\hline $\begin{array}{l}\text { (i) Domestic and foreign debt records are complete, updated and } \\
\text { reconciled on a monthly basis with data considered to be of high } \\
\text { integrity. Comprehensive management and statistical reports are } \\
\text { produced at least quarterly }\end{array}$ & A & \multirow{3}{*}{$\mathrm{A}$} & B & \multirow{3}{*}{ A } \\
\hline $\begin{array}{l}\text { (ii) Most cash balances are calculated and consolidated at least } \\
\text { weekly, but some EBUs remain outside the arrangement }\end{array}$ & B & & $\mathrm{A}$ & \\
\hline $\begin{array}{l}\text { (iii) Central government's contracting of loans, and issuance of } \\
\text { guarantees are made against transparent criteria and fiscal targets, and } \\
\text { always approved by a single responsible government entity }\end{array}$ & $\mathrm{A}$ & & A & \\
\hline
\end{tabular}

79. Domestic and foreign debt, including guarantees, are effectively recorded, managed and reported by the debt policy and strategy unit in MoFED in conjunction with the Bank of Mauritius (BOM). The Commonwealth Secretariat Debt Recording and Management System (CS-RMS) is used to record debts. BOM records and reconciles monthly all central government debts in its copy of the CS-DRMS database while the MoFED Debt Unit records and reconciles monthly all other public sector debt and guarantees including those of public enterprises in their copy of CS-DRMS database. The information in BOM is submitted manually to the Debt Unit, for consolidation into a debt report that is made publically available on the MoFED website, not later than one month after the end of every quarter and annually in Statement $J$ of the 
government financial statements. The director of audit indicates that domestic and external debts totaling MUR8,335 million and MUR3,471 million respectively incurred by agencies, local government and public enterprises and guaranteed by government as of December 31, 2009, were fully disclosed in the statement of public debt and in the statement of contingent liabilities.

80. Central budgetary government cash holdings are monitored, consolidated, and reconciled on a daily basis. The reconciliation statements are available as and when required from the TAS. However, the consolidation excludes cash held by extra-budgetary units. This was not an issue addressed in the 2007 assessment, although cash balances at EBUs were significantly less substantial at that time.

\section{The procedures for contracting loans and issuing guarantees are made against} transparent criteria and fiscal targets. The Public Debt Management Act 2008 sets out a comprehensive regime for establishment of a debt strategy, management of debt and accountability including reporting. Key provisions include: (i) a borrowing ceilings (60 percent GDP); (ii) identification in the budget of external financing estimates by loan; (iii) disaggregated reporting in the budget of actual and forecast changes in debt stock by central budgetary government, EBUs, subnational government and public enterprises; (iv) granting of sole power to borrow to the MoFED; (v) a requirement that all loan agreements or guarantees are submitted to the legislature within 15 working days; and (vi) full quarterly in-year and annual reporting on the public debt. The ceilings, debt strategy, accountability and reporting requirements have been observed during the period of the assessment, although the indications are that the debt stock is increasing and without remedial action the ceiling may be breached in the near future.

\section{PI-18. Effectiveness of payroll controls}

This indicator has three dimensions that assess the: (i) degree of integration and reconciliation between personnel records and payroll data; (ii) timeliness of changes to personnel records and the payroll; (iii) internal controls of changes to personnel records and the payroll; and (iv) existence of payroll audits to identify control weaknesses and/or ghost workers.

\begin{tabular}{|c|c|c|c|c|}
\hline $\begin{array}{l}\text { 2010 Assessment (scoring method M1) } \\
\text { Dimension: }\end{array}$ & & & & \\
\hline $\begin{array}{l}\text { (i) Personnel and payroll data are not directly linked but the payroll is } \\
\text { supported by full documentation for all changes made to personnel } \\
\text { records each month and checked against the previous month's payroll } \\
\text { data }\end{array}$ & B & \multirow{4}{*}{$\mathrm{B}+$} & B & \multirow{4}{*}{$\mathrm{B}+$} \\
\hline $\begin{array}{l}\text { (ii) Required changes to the personnel records and payroll are } \\
\text { updated monthly generally in time for the following month's } \\
\text { payments. Retroactive adjustments are rare }\end{array}$ & $\mathrm{A}$ & & $\mathrm{A}$ & \\
\hline $\begin{array}{l}\text { (iii) Authority to change records and payroll is restricted and results in } \\
\text { an audit trail }\end{array}$ & $\mathrm{A}$ & & $\mathrm{A}$ & \\
\hline $\begin{array}{l}\text { (iv) A strong system of payroll audits exists to identify control } \\
\text { weaknesses and/or ghost workers }\end{array}$ & A & & A & \\
\hline
\end{tabular}


82. Payroll and personnel records are not integrated but payroll changes are authorized and fully documented. Personnel records are maintained manually at each ministry/department and a process to progressively computerize the records has been initiated in 11 pilot sites. The ministries/departments manually submit approved payroll related changes to Central Information Systems Division (CISD) for processing in the payroll system. The payroll system is not linked directly to TAS; payment information generated in the payroll system is submitted manually for processing in TAS.

83. Changes to personnel records and payroll are updated monthly in time for the following month's payments. The changes are approved by authorized personnel officers in ministries/departments. After processing the changes, the payroll is reviewed by the ministry for accuracy. A computerized identity card and attendance system which controls the establishment and monitor attendance of personnel is currently being transferred to a fingerprint-based system.

84. Adequate and appropriate internal controls relating to changes in personnel records and payroll exist and are complied with. Authority to change records and payroll is restricted and lies with the accounting officer who has authority to delegate the responsibility to an officer not below the rank of assistant finance officer or executive officer. The officer approves the variation forms that are prepared monthly and submitted by line ministry to CISD for payroll processing. CISD verifies the officer's signature before any processing is done. After processing the payroll, CISD submits the monthly payroll lists back to the ministries to be confirmed and signed. At the ministry level, actual payments are checked against previous month's payment.

85. After approval by ministries, the signed payrolls are submitted to the treasury which enters them manually in TAS, and processes the payments to employee's individual bank accounts. All payment and deduction details are also manually transcribed into individual Salary Cards kept in Finance Sections in the ministries/departments for post-payroll verification. The procedures are well documented in the Financial Management Manual.

86. Both the internal audit unit and the director of audit perform compliance testing of the internal controls of the payroll at ministry/department level. The director of audit performs substantive testing of the payroll and confirms the existence of an adequate audit trail during year-end audit. The auditors have reported that an adequate audit trail exists and that no major issues have arisen during the last three years. However, no IT system audit has been conducted on the payroll system during the period of review.

\section{PI-19. Competition, value for money in controls in procurement}

This indicator has three dimensions which assess the: (i) use of open competition for award of contracts that exceed the nationally established monetary threshold for small purchases; (ii) justification for use of less competitive procurement methods; and (iii) existence and operation of procurement of complaints mechanism. 


\begin{tabular}{|c|c|c|c|c|}
\hline Dimension (scoring method M1) & \multicolumn{2}{|c|}{$\begin{array}{l}\text { Score } \\
2010\end{array}$} & \multicolumn{2}{|c|}{$\begin{array}{l}\text { Score } \\
2007\end{array}$} \\
\hline $\begin{array}{l}\text { (i) Accurate data on the method used to award public contracts } \\
\text { exists and shows that more than } 75 \text { percent of contracts above the } \\
\text { threshold are awarded on the basis of open competition }\end{array}$ & $\mathrm{A}$ & \multirow{3}{*}{ A } & $\mathrm{A}$ & \multirow{3}{*}{$\mathrm{B}+$} \\
\hline $\begin{array}{l}\text { (ii) Other less competitive methods, when used, are justified in } \\
\text { accordance with clear regulatory requirements }\end{array}$ & $\mathrm{A}$ & & A & \\
\hline $\begin{array}{l}\text { (iii) A process (defined by legislation) for submitting and } \\
\text { addressing procurement process complaints is operative and } \\
\text { subject to oversight of an external higher authority }\end{array}$ & B & & $\mathrm{C}$ & \\
\hline
\end{tabular}

87. Consistent with the 2006 Public Procurement Act, open competitive procurement arrangements exist for contracts above the national threshold for small contracts (currently MUR5 million). The Procurement Policy Office (PPO) collects data on all the contracts above MUR500,000 through the quarterly reporting by Procurement Boards; these account for 90 percent of procurement in terms of value. According to these statistics, open competitive procurement accounts for 88 percent in 2008 and 77 percent in 2009 of the number of contracts above the small contracts threshold. In terms of value, the share of contracts above the threshold was 98 percent in 2008 and 92 percent in 2009. Assessment of internal control systems, confirm adequate oversight of the procurement systems and transactions, including consistency of methods within thresholds.

88. The data collected by PPO shows that, in terms of value, the percentage of noncompetitive contracts awards above the threshold of MUR5 million was 2 percent in 2008 and 8 percent in 2009. Justification for non-competitive procurement is required under the law and systems to record it are in place and subject to audit. According to Public Procurement Act (PPA) 2008: when a public body uses a method of procurement other than open advertised bidding or, in the case of procurement of consultancy services, a method other than competitive methods, it shall note in the record of the procurement proceedings the grounds for the choice of the procurement method. PPO receives quarterly reports from the PBs and checks the justifications and requires additional information as needed. PPA justifications for noncompetitive procedures include: original equipment manufacturers, unique qualification of consultants, limited number of suppliers, and continuity of supply. In a few cases the use of less competitive methods is due to underestimation of the contract value. It is however noted that there has recently been an increase in the use of less competitive methods above the national threshold for small contracts, so the government needs to ensure that this indicator continues to be subject to rigorous oversight.

89. A complaints mechanism operated by an Independent Review Panel (IRP) is now operational but as yet not fully effective. All data for resolution of complaints is subject to public scrutiny and is published on the PPO website. However, the fact that complaints rulings are not binding introduces some risk that procuring entities may not enforce the IRP decisions, which puts in question the effectiveness of the complaints mechanism. 


\section{PI-20. Effectiveness of internal controls for non-salary expenditure}

This indicator has three dimension which assess the: (i) effectiveness of expenditure commitment; (ii) comprehensiveness, relevance, and understanding of other internal control rules and procedures controls; and (iii) degree of compliance with rules for processing and recording transactions.

\begin{tabular}{|c|c|c|c|c|}
\hline 2010 Dimension Ratings (scoring method M1) & \multicolumn{2}{|c|}{$\begin{array}{l}\text { Score } \\
2010\end{array}$} & \multicolumn{2}{|c|}{$\begin{array}{l}\text { Score } \\
2007\end{array}$} \\
\hline $\begin{array}{l}\text { (i) Comprehensive expenditure commitment controls are in } \\
\text { place and effectively limit commitments to projected cash } \\
\text { availability and approved budget allocations }\end{array}$ & $\mathrm{A}$ & \multirow{3}{*}{ A } & A & \multirow{3}{*}{ A } \\
\hline $\begin{array}{l}\text { (ii) Other internal control rules and procedures are relevant and } \\
\text { incorporate a comprehensive and generally cost effective set of } \\
\text { controls, which are widely understood }\end{array}$ & $\mathrm{A}$ & & A & \\
\hline $\begin{array}{l}\text { (iii) Compliance with rules is very high and any misuse of } \\
\text { simplified and emergency procedures is insignificant }\end{array}$ & $\bar{A}$ & & A & \\
\hline
\end{tabular}

90. An effective and comprehensive expenditure commitment control system (linked to TAS) is in place and effectively limits commitments to approved budget allocations and projected cash availability. Commitment and payment thresholds are established in the TAS system once the accountant-general issues the annual or updated warrant to incur expenditure; these are based on a commitment-based payment cash flow forecast within the approved budget framework. The TAS system provides an in-built control mechanism for commitment registration that does not accept any commitment that would generate a payment above the authorized threshold, unless specific and appropriate authority is granted through a reallocation or supplementary approval.

91. A comprehensive and relevant internal control framework exists designed to ensure that government resources are used economically, efficiently and effectively and assets are safeguarded. The internal control procedures and rules are documented in the Financial Management Manual (FMM), Personnel Management Manual, Financial Circulars, and Financial Instructions. The FMM is being revised (as it was issued in 1990) to incorporate the internal control changes documented in financial instructions and circulars taking into account the improved financial legislation supporting the fiscal reforms. Training for the internal controls is however minimal and mostly informal: an aspect that could potentially hinder (although in practice does not appear to have) the ability to understand the procedures, especially by new employees, and impact on compliance with internal controls.

\section{The extent of compliance with the internal controls and recording transactions}

is high. Transactions are recorded in a timely manner in the TAS by the finance officers in ministries/departments, and transaction information is regularly reviewed. The management and officials also comply with the internal controls. The internal auditor undertakes regular reviews of internal controls and confirms management and officials consistently comply with internal 
controls including those used for emergency procurement procedures. Reviews are also done on other ministries/departments on a rotating basis. The director of audit also performs compliance testing during the year-end audit and has not, in his audit reports for the past three years, reported any adverse comments regarding the processing and recording of financial transactions.

\section{Self-accounting units prepare and record their own financial information, which} is also subjected to audit by the director of audit. The units follow the same internal control procedures as non self-accounting ministries and departments.

\section{The Internal Control Cadre (internal audit unit) has 22 teams permanently} positioned to perform internal audit in large ministries/departments, and three roving teams that carry out internal audit in other ministries/departments on a rotating basis. The unit does not perform internal audits in EBU units, which have their own individual internal auditors. The unit's mandate is set out in the MoFED Circular No.12 of 2005(Internal Audit Regulation). There is currently no independent legislation that supports the establishment of internal audit and provides its functions. Internal Audit Charters exists in all entities where internal audit is involved and these are signed by accounting officers. As at December 30, 2009, the unit had 77 officials out of an establishment of 117 (with 16 above the rank of assistant manager). More than 50 percent of the staff have professional accounting or audit qualifications. Junior staff, mainly in the position of internal control officers, require more mentoring and training to acquire appropriate professional qualifications.

\section{PI-21. Effectiveness of internal audit}

This indicator has three dimensions that assess the: (i) coverage and quality of internal audit function; (ii) frequency and distribution of reports; and (iii) extent of management response to internal audit findings.

\begin{tabular}{|l|l|l|l|l|}
\hline 2010 Dimension Ratings (scoring methodology M1) & \multicolumn{2}{|c|}{ Score } & \multicolumn{2}{|c|}{ Score } \\
\hline $\begin{array}{l}\text { (i) Internal audit is operational for the majority of central government } \\
\text { entities and substantially meets professional standards. It is focused on } \\
\text { systematic issues (at least 50percent of staff time) }\end{array}$ & $\mathrm{B}$ & $\mathrm{B}$ & \\
\cline { 1 - 2 } $\begin{array}{l}\text { (ii) Reports adhere to a fixed schedule and are distributed to the } \\
\text { audited entity, ministry of finance and the Supreme Audit Institution }\end{array}$ & $\mathrm{A}$ & $\mathrm{B}+$ & $\mathrm{A}$ & $\mathrm{B}+$ \\
\cline { 1 - 2 } $\begin{array}{l}\text { (iii) Prompt and comprehensive action is taken by many (but not all) } \\
\text { managers }\end{array}$ & $\mathrm{B}$ & $\mathrm{B}$ & \\
\cline { 1 - 3 } & & &
\end{tabular}

95. The unit applies internal audit methodology that is in line with International Internal Audit Standards and the Institute of Internal Auditors (IIA) guidelines. The methodology is risk based and addresses systemic issues. The unit has not yet conducted IT audit and hence IT related internal audits review are conducted on inputs and outputs, but without detailed review of internal computer processes. 
96. Internal audit reports are issued, once finalized, to the audited entities, MoFED, Director, Office of the Public Sector Governance (OPSG) and the Director of Audit (on request and followed up at least annually). Internal audit is carried out according to an agreed audit plan between the Internal Audit Unit and the audited entity prior to the start of the audit. The annual audit plan is approved by the accounting officer at the start of each year. It clearly defines the timing, extent of the audit coverage and the audit procedures to be followed. The submission of the audit findings and the audit report adheres to a fixed schedule.

97. Management response varies across MDAs. Action is taken by many (but not all) Accounting Officers on major issues. At the end of an internal audit an exit meeting is held, where the draft internal audit report, with recommendations, is discussed with management. Management is required to prepare an action plan on agreed recommendations and the timing of their implementations. There is no evidence of formal follow-up and monitoring of recommendations made by internal audit. Similar issues are repeated from one year to the next, this is also noted in director of audit reports; an indication of weakness in implementation of recommendations. The Office of Public Sector Governance (OPSG), in the Prime Minister's office, has been strengthened to address this issue, monitor the implementation of the recommendations, and report to the Public Service Commission where there is limited or no implementation. The initiative to establish audit committees for central government entities, from 2006, was not successful and none is currently operational, this effectively limits the demand for effective resolution of internal audit queries.

\section{E. Accounting, Recording, and Reporting}

\section{PI-22. Timeliness and regularity of accounts reconciliation}

This indicator has two dimensions and assesses the: (i) regularity of bank reconciliations; and (ii) regularity of reconciliation and clearance of suspense accounts and advances.

\begin{tabular}{|c|c|c|c|c|}
\hline $\begin{array}{l}2010 \text { Assessment (scoring method M2) } \\
\text { Dimensions: }\end{array}$ & \multicolumn{2}{|c|}{$\begin{array}{l}\text { Score } \\
2010\end{array}$} & \multicolumn{2}{|c|}{$\begin{array}{l}\text { Score } \\
2007\end{array}$} \\
\hline $\begin{array}{l}\text { (i) Bank reconciliation for all centrally managed bank accounts take } \\
\text { place at least monthly at aggregate and detailed levels, usually within } \\
\text { four weeks of the end of the period }\end{array}$ & A & $\Lambda$ & $\mathrm{A}$ & $\Lambda$ \\
\hline $\begin{array}{l}\text { (ii) Reconciliation and clearance of suspense accounts and advances } \\
\text { take place at least quarterly, within a month from the end of the period } \\
\text { and with few balances brought forward }\end{array}$ & $\mathrm{A}$ & A & $\mathrm{A}$ & A \\
\hline
\end{tabular}

98. Bank reconciliations for all central government managed bank accounts takes place daily with follow-up on outstanding issues undertaken monthly, within four weeks from end of month. The government has bank accounts mainly in the State Bank of Mauritius and in the Central Bank of Mauritius. Payments for central budgetary government are made through a Single Treasury Account (at BOM) and appropriately recorded in TAS. Reconciliation 
statements are available through the TAS. Self-accounting entities, prepare their own bank reconciliations, on a monthly basis.

99. There are no suspense accounts maintained in the general ledger for central budgetary government, deposit and advance accounts are reconciled monthly. Transactions, mainly unknown deposits, remain in the bank reconciliations for a maximum of three months; a period when investigation are undertaken to identify the nature of the deposit. Once this is determined the un-reconciled deposit is cleared and allocated to the correct general ledger revenue account. There exist procedures for the granting of employee's advances mainly car loans; monthly reconciliations are conducted on these advances accounts. Other advances, besides car loans, are not significant.

\section{PI-23. Availability of information on resources received by service delivery units}

This indicator assesses the extent to which information, is collected and processed, that demonstrate resources (cash and kind) are received by front line service delivery units.

\begin{tabular}{|l|c|c|}
\hline $\begin{array}{l}\text { 2010 Assessment (scoring method M1) } \\
\text { Dimensions: }\end{array}$ & $\begin{array}{c}\mathbf{2 0 1 0} \\
\text { Score }\end{array}$ & $\begin{array}{c}\mathbf{2 0 0 7} \\
\text { Score }\end{array}$ \\
\hline $\begin{array}{l}\text { Routine data collection or accounting systems provide reliable } \\
\text { information on all types of resources received in cash and in kind by } \\
\text { both primary schools and health clinics across the country. }\end{array}$ & A & A \\
\hline
\end{tabular}

100. Resources disbursed to service delivery units are recorded in the TAS and provide reliable information on the resources available, by zone, to frontline service delivery units. The chart of accounts in TAS allows capture and reporting of transactions-revenue and expenditures-relating to a cost centre. The budgets for frontline service delivery units, such as primary schools and primary health clinics, are however organized and administered by zone (given the small size of frontline service delivery units in Mauritius); these are responsible for a cluster of service delivery units. Transactions relating to frontline delivery units like schools and health centers are captured in TAS, by the respective ministry, in the allocated zonal cost centre codes, minimal amounts are disbursed and administered at unit level. There is no evidence of any leakage of resources to frontline service delivery units. For any direct receipts received by schools from third parties (parents) financial statements are prepared at school level presented to the relevant third parties (parent community).

\section{PI-24. Quality and timeliness of in-year budget reports}

This indicator has three dimensions that assess the: (i) scope of reports in terms of coverage and compatibility with budget estimates; (ii) timeliness of the issue of reports; and (iii) quality of information. 


\begin{tabular}{|c|c|c|c|c|}
\hline $\begin{array}{l}\text { 2010 Assessment (scoring method M1) } \\
\text { Dimensions: }\end{array}$ & \multicolumn{2}{|c|}{$\begin{array}{l}2010 \\
\text { Score }\end{array}$} & \multicolumn{2}{|c|}{$\begin{array}{l}2007 \\
\text { Score }\end{array}$} \\
\hline $\begin{array}{l}\text { (i) Classification allows comparison to budget but only with some } \\
\text { aggregation, expenditure is covered at both commitment and } \\
\text { payment stages }\end{array}$ & A & \multirow{3}{*}{ A } & $\mathrm{B}$ & \multirow{3}{*}{$\mathrm{B}+$} \\
\hline $\begin{array}{l}\text { (ii) Reports are prepared quarterly or more frequently issued within } \\
\text { four weeks of the end of the period }\end{array}$ & A & & $\mathrm{B}$ & \\
\hline (iii) There are no material concerns about data accuracy & A & & A & \\
\hline
\end{tabular}

101. In-year budget execution reports for ministries and departments are available in TAS which allows comparison between budget and actual spending. Following approval by parliament the budget appropriations for ministries and departments are manually uploaded into the TAS system at the level of MoFED. Ministries/departments record transactions in the system and budget execution reports can be generated at any time. The information includes expenditure at both commitment and payments stages. Transfers to EBUs are included in these reports, but detailed extra-budgetary units expenditures or own revenues, are not recorded in the TAS. Therefore, it is currently not feasible to compare and monitor fully aggregated actual vs. budget performance data for all central government entities including EBUs.

102. In-year budget reports can be generated from the TAS system at any time. These are usually generated on a monthly basis and published on the website of MoFED and hence accessible to the public at large. These reports exclude EBUs operations.

103. Quality of in-year budget information is considered to be high. The quality is supported by the fact that there is high degree of compliance with requirements relating to processing and recording transactions (PI-20). No significant data accuracy concerns have been expressed by the director of audit and the internal audit unit.

\section{PI-25. Quality and timeliness of annual financial statements}

This indicator has three dimensions that assess the: (i) completeness of the financial statements; (ii) timeliness of submission of the financial statements; and (iii) accounting standards used.

\begin{tabular}{|l|c|c|c|}
\hline Dimensions to be assessed (Scoring method M1) & \multicolumn{2}{|c|}{$\begin{array}{c}2010 \\
\text { Score }\end{array}$} & \multicolumn{2}{|c|}{$\begin{array}{c}2007 \\
\text { Score }\end{array}$} \\
\hline $\begin{array}{l}\text { (i) A consolidated government statement is prepared annually and } \\
\text { includes full information on revenue, expenditure and financial } \\
\text { assets and liabilities }\end{array}$ & A & A & \\
\cline { 1 - 2 } $\begin{array}{l}\text { (ii) The statement is submitted for external audit within six months } \\
\text { of the end of the fiscal year }\end{array}$ & A A & A & A \\
\cline { 1 - 2 } (iii) IPSAS or corresponding national standards are applied & A & A & \\
\cline { 2 - 3 }
\end{tabular}

104. The financial statements of budgetary central government and of individual EBUs are prepared annually and include full information on revenue, expenditure and financial 
assets and liabilities. The consolidated budgetary central financial statement is prepared to comply with requirements of the Constitution, Sec 103 -109, and Finance and Audit Act. The financial statements are prepared on a cash basis using a chart of accounts based on the GFSM 2001 manual classification system. To comply with the requirements in Finance and Audit Act, Section 19.3, the financial statements include detailed statements of financial assets and liabilities as well as the financial position (financial assets advances, cash and financial liabilities short-term borrowings). In addition to regulatory requirements, IPSAS cash basis standards are applied by the inclusion of the following statements: (i) cash flow statement; (ii) notes on accounting policies; and (iii) comparison with the budget. Some accrual based information relating to financial assets and liabilities is also disclosed in the statement of financial position. The presentation is consistent from one year to the next. A number of EBUs are also utilizing IPSAS (either cash or accrual according to the nature of their operations) in preparing their financial statements.

105. The financial statements are regularly submitted to the director of audit within the statutory stipulated period of six months of the end of the fiscal year. During the period of review the government financial statements were submitted for external audit within four-five months of the end of the fiscal year.

\begin{tabular}{|c|c|c|}
\hline Fiscal Year & Year-end & Date Financial Statement Submitted to NAO \\
\hline 2007-08 & June 30 & November 7, 2008 \\
\hline 2008-09 & June 30 & November 20, 2009 \\
\hline July-Dec 2009 & December 31 & May 31, 2010 \\
\hline
\end{tabular}

\section{F. External Scrutiny and Audit}

\section{PI-26. Scope, nature, and follow-up of external audit}

This indicator has three dimensions that assess the: (i) scope/nature of the audit performed (including adherence to auditing standards); (ii) timeliness of submission of audit reports to legislature; and (iii) evidence of follow-up on audit recommendations.

\begin{tabular}{|c|c|c|c|c|}
\hline $\begin{array}{l}\text { 2010 Assessment (scoring method M1) } \\
\text { Dimensions: }\end{array}$ & \multicolumn{2}{|c|}{$\begin{array}{c}2010 \\
\text { Score }\end{array}$} & \multicolumn{2}{|c|}{$\begin{array}{l}2007 \\
\text { Score }\end{array}$} \\
\hline $\begin{array}{l}\text { (i) All entities of the central government are audited annually } \\
\text { covering revenue, expenditure and assets/liabilities. A full range } \\
\text { of financial and performance audits are performed that adhere to } \\
\text { recognized auditing standards focusing on significant and } \\
\text { systemic issues }\end{array}$ & $B$ & & B & \\
\hline $\begin{array}{l}\text { (ii) Audit reports are submitted to the legislature within four } \\
\text { months of the end of the period covered and in the case of } \\
\text { financial statements from their receipt by the audit office }\end{array}$ & $\mathrm{A}$ & $\mathrm{B}+$ & $\mathrm{A}$ & $\mathrm{B}+$ \\
\hline $\begin{array}{l}\text { (iii) A formal response is made in a timely manner, but there is } \\
\text { limited evidence of systematic follow-up }\end{array}$ & B & & B & \\
\hline
\end{tabular}


106. Under the provisions of the Finance and Audit Act 2008, the director of audit, who heads the National Audit Office (NAO), the supreme audit institution (SAI), undertakes on an annual basis a comprehensive independent annual financial audit. This audit covers the headquarter units of all ministries and departments and the majority of their divisions/subdivisions and EBUs. Due to limited resources and low risks the remaining units are audited on a five-year rotational basis. The NAO annual report for 2009 notes that the total population of units for audit as at the end of December 2009 equaled 1,468. The NAO activity statistics, shown below (Table 13) for the 18-month period, July 2009 to December 2010, show 82 percent of planned audits have been undertaken including 76 percent related to ministries and departmental units. The report also notes that the number of units audited has risen (from 444 to 778 between FY2007/08 and FY2009) significantly and that this, given the existence of some staff shortages, is regarded as a satisfactory level of performance. The NAO also undertook three audits during 2009 , including an assessment of the program-based budgeting implementation.

Table 13. Mauritius: Government Financial Accounts Audited (July 2008-December 2010)

\begin{tabular}{lrrr}
\hline & $\begin{array}{r}\text { Planned } \\
\text { units }\end{array}$ & $\begin{array}{r}\text { Actual } \\
\text { Units }\end{array}$ & $\begin{array}{r}\text { Completion } \\
\text { percent }\end{array}$ \\
\hline Ministries & 402 & 304 & 75.6 \\
Statutory bodies & 201 & 164 & 81.6 \\
Local authorities & 133 & 133 & 100.0 \\
Special funds & 51 & 31 & 60.8 \\
Rodrigues & 142 & 129 & 90.8 \\
Other funds & 17 & 17 & 100.0 \\
Total & 946 & 778 & 82.2 \\
Total population of accounts at December 31, 2010 was 1,468 & \\
\hline
\end{tabular}

Source: Ministry of Finance and Economic Development

107. The director of audit has adopted a risk-based methodology and audit manual as of July 1, 2009, consistent with the directives of the INTOSAI. The audit approaches include financial certification audits, performance reviews/evaluations, value for money audits, IT audit and issues relating to corporate governance. The office has an establishment of 150 officers comprising professional accountants and technical staff. To ensure compliance with INTOSAI standards, the director of audit has established new quality assurance guidelines and has agreed the NAO be subject to peer review by African Organization of Supreme Audit Institutions (AFROSAI). A quality assurance unit has also been established to facilitate quality review work.

108. The director of audit annual report on the accounts of the GoM, for the 18-month period ending December 31, 2009, was submitted to the Vice Prime Minister and MoFED, on the July 12, 2010. The report, which includes the audited financial statements, is then tabled in the National Assembly and placed on the homepage of the NAO website. This is within the 
seven months of the end of the fiscal year and within two months of submission of the financial statements to the NAO. This sustains the reporting performance for earlier annual audits. The report notes that out of the 110 plus EBUs some 14 sets of financial statements (a few for multiple years) related to EBUs were outstanding, and 20 EBU financial statements primarily relating to 2008-09 remained under examination.

\section{The NAO report documents the recommendations of the director of audit and the} responses of Accounting Officers' agreed follow-up actions. Accounting offices (referred to as controlling officers) are required to provide a formal response within three weeks with an action plan for follow-up of the Director of Audits' recommendations. Follow-up of these plans for all material issues is undertaken by the Office of Public Sector Governance (OPSG).

\section{PI-27. Legislative scrutiny of the annual budget law}

This indicator has four dimensions that assess the: (i) scope of the legislature's scrutiny; (ii) extent to which the legislature's procedures are well-established and respected;

(iii) adequacy of time for the legislature to provide a response to budget proposals; and (iv) rules for in-year amendments to the budget without ex ante approval by the legislature.

\begin{tabular}{|c|c|c|c|c|}
\hline $\begin{array}{l}2010 \text { Assessment (scoring method M1) } \\
\text { Dimensions: }\end{array}$ & \multicolumn{2}{|c|}{$\begin{array}{l}\text { Score } \\
2010\end{array}$} & \multicolumn{2}{|c|}{$\begin{array}{l}\text { Score } \\
2007\end{array}$} \\
\hline $\begin{array}{l}\text { (i) The legislatures review covers fiscal policies and } \\
\text { aggregates for the coming year term as well as detailed } \\
\text { estimates of expenditure and revenue }\end{array}$ & B & \multirow{4}{*}{$\mathrm{C}+$} & B & \multirow{4}{*}{$\mathrm{B}+$} \\
\hline $\begin{array}{l}\text { (ii) Simple procedures exist for the legislature's budget } \\
\text { review they are respected but they are not comprehensive }\end{array}$ & $\bar{C}$ & & B & \\
\hline $\begin{array}{l}\text { (iii) The legislature has at least the equivalent of one } \\
\text { working month to review the budget proposals }\end{array}$ & B & & B & \\
\hline $\begin{array}{l}\text { (iv) Clear rules exist for in-year budget amendments by the } \\
\text { executive and are usually respected, but they allow } \\
\text { extensive administrative reallocations }\end{array}$ & B & & A & \\
\hline
\end{tabular}

110. The scope of the legislature's review covers medium-term expenditure projections, and some limited review of medium-term priorities, although this occurs at the conclusion of the budget process. Discussions in the legislature have been confined to the annual budget speech which outlines key fiscal policies and aggregates and details of the expenditure estimates contained in the program, sub-program of item of expenditure. There is little detailed discussion of the medium-term fiscal framework or medium-term priorities as this was not presented in the estimates in the period under review.

111. The legislatures review process relies on a full sitting of the parliament, members however sit only on a part-time basis. There are no specialized subcommittees, and support staff is limited to a small office of two clerks. Given the limited nature of legislative review, which, by not addressing the key fiscal and economic policies cannot be considered 
comprehensive in scope, this dimension is scored as a C, lower than the assessment in the 2007 assessment, although this is due to a reassessment of the existing procedures against the PEFA, rather than any deterioration in procedures.

112. The legislature is provided 30 days to review the budget, in accordance with the constitution. A maximum number of days are determined by the president of the assembly, after consultation with the members. Although allowed 30 days, the actual time spent deliberating the budget is usually around one to two weeks of very intensive sitting. This raises concern over the effectiveness of current levels of scrutiny.

\section{Clear rules for in-year budget amendments are laid out in the constitution,} requiring a supplementary appropriation for any unappropriated expenditures. These rules are usually respected, however over recent years there has been a large expansion in the number of authorizations for unappropriate expenditure at the bureaucratic level, in advance of the supplementary appropriations. It is unclear what would eventuate if the legislature did not approve those authorizations after the fact.

\section{PI-28. Legislative scrutiny of external audit reports}

This indicator has three dimensions that assess the: (i) timeliness of examination of audit reports by the legislature; (ii) extent of hearing on key findings undertaken by the legislature; and (iii) issuance recommended actions by the legislature and implementation by the executive.

\begin{tabular}{|l|c|c|c|c|}
\hline Dimensions to be assessed (scoring method M1) & \multicolumn{2}{|c|}{$\begin{array}{c}\mathbf{2 0 1 0} \\
\text { Score }\end{array}$} & \multicolumn{2}{|c|}{$\begin{array}{c}\mathbf{2 0 0 7} \\
\text { Score }\end{array}$} \\
\hline (i) The reports of the legislature review have not been compiled & $\mathrm{D}$ & & $\mathrm{D}$ & \\
\cline { 1 - 2 } $\begin{array}{l}\text { (ii) In depth hearings have taken place with MoFED and responsible } \\
\text { controlling officers, but in camera and without any reports being } \\
\text { produced }\end{array}$ & $\mathrm{A}$ & $\mathrm{A}$ & \\
\cline { 1 - 2 } (iii) No recommendations have been issued by the legislature & $\mathrm{D}$ & & $\mathrm{D}+$ \\
\cline { 1 - 2 }
\end{tabular}

114. There are no reports that outline, in a timely manner, the results of examination of the reports of the director of audit by the PAC during the period of the assessment and of the key findings of the legislature. Under the current Standing Orders and Rules of the National Assembly 1995 (Section 69.2), a Public Accounts Committee (PAC) of the parliament is required to be established with the primary duty to examine the audited accounts of government as laid before the committee by the director of audit. It is understood from discussion with the office of the clerk to the parliament that a PAC was established and meetings were held during the period of the assessment. It is also understood that a number of hearings were also held where accounting officers were required to answer questions related to the annual audit report and that the director of audit and the accountantgeneral were in attendance. However although minutes of the meetings of these hearings 
were taken, no reports of the proceedings have been issued and no recommendations have been made.

115. Furthermore, these meetings were held in camera without any disclosure of the proceedings and explicit evidence of implementation of recommendations cannot be confirmed. It is also noted that local practice is to seal the evidence of previous committee proceedings once a new parliament has been elected. Unless any new PAC revisits the audit reports this practice effectively limits the continuity, scope and timeliness of the PAC review process.

116. The absence of any recommendations by the PAC during the period of the assessment undermines a key component in the PFM accountability cycle and severely limits the effective oversight of the executive arm by the legislature. The reasons behind the breakdown of this process appear to stem from: (i) failure to recognize and prioritize the importance of this process; (ii) the limited time available to members of the parliament; and (iii) the limited allocation of resources for managing the process. It is understood that, following the recent election, the new parliament addressed the issues relating to frequency of hearings and recording of proceedings and the PAC is now meeting on a regular basis, however the resources needed to support the process remain limited.

\section{G. Donor Practices}

\section{D-1. Predictability of direct budget support}

This indicator has two dimensions that assess the: (i) annual deviation of actual budgetary support from the forecast provided by the donor agencies at least six weeks prior to the government submitting its budget proposals to the legislature; and (ii) the in-year timeliness of donor disbursements.

\begin{tabular}{|c|c|c|c|c|}
\hline Dimensions to be assessed (scoring method M1) & \multicolumn{2}{|c|}{$\begin{array}{c}2010 \\
\text { Score }\end{array}$} & \multicolumn{2}{|c|}{$\begin{array}{l}2007 \\
\text { Score }\end{array}$} \\
\hline $\begin{array}{l}\text { (i) In at least two of the last three years direct budget support } \\
\text { outturn fell short of the forecast by more than } 5 \text { percent }\end{array}$ & $\mathrm{D}$ & \multirow[t]{2}{*}{$\mathrm{D}$} & $\mathrm{A}$ & \multirow[t]{2}{*}{$\mathrm{A}$} \\
\hline (ii) In-year timeliness of donor disbursements & $\mathrm{D}$ & & $\mathrm{A}$ & \\
\hline
\end{tabular}

\section{The annual deviation of estimated direct budget support to actual provision} of funds has been substantial over the years under consideration. In 2007-08, actual support came in 45 percent below estimated, in 2008-09, support came in 24 percent above, and in July-December 2009 support came in 56 percent below estimated (Table 14). As budget support has fallen short in two years out of three, this dimension scores a D, a large change from the A assessed in 2007. However this does not imply a lack of predictability in donor disbursements but rather issues related to conditionality, and active management by the government of donor disbursements in accordance with cash flow requirements. This 
approach can be considered relatively prudent for the period under review, given the backdrop of the global financial crisis.

Table 14. Total Direct Budget Support Actual versus Estimated

\begin{tabular}{lrrr}
\hline & $\begin{array}{r}\text { 2007-08 } \\
\text { MUR mIn }\end{array}$ & $\begin{array}{r}\text { 2008-09 } \\
\text { MUR mln }\end{array}$ & $\begin{array}{r}\text { July-Dec 2009 } \\
\text { MUR mln }\end{array}$ \\
\hline Budgeted & 5,155 & 6,113 & 7,205 \\
Actual & 2,834 & 7,547 & 3,182 \\
Difference & $-2,321$ & 1,434 & $-4,023$ \\
Percent variation & -45.0 & 23.5 & -55.8 \\
\hline
\end{tabular}

Source: Ministry of Finance and Economic Development

118. In assessing the causes of the variations, the grant support and loan support have been separated out, as the factors driving each of them are quite different. The reasons for the large percentage variation in grant (Table 15) are twofold. In 2007-08, a large EU budget support for the sugar sector was deferred because conditionality requirements were not met due to prolonged negotiations at the political level in respect of reform, resulting in the deferral of MUR2.2 billion of grants to the following year. The second factor is the fact that the government has, on a number of occasions, requested that grant payments be deferred until the following year for cash flow reasons.

Table 15. Direct Budget Support Grants: Actual versus Estimates

\begin{tabular}{lrrr}
\hline & $\begin{array}{r}\text { 2007-08 } \\
\text { MUR mln }\end{array}$ & $\begin{array}{r}\text { 2008-09 } \\
\text { MUR mln }\end{array}$ & $\begin{array}{r}\text { July-Dec 2009 } \\
\text { MUR mln }\end{array}$ \\
\hline Budgeted & 2,935 & 4,025 & 2,624 \\
Actual & 454 & 2,781 & 3,182 \\
Difference & $-2,481$ & $-1,244$ & 558 \\
Percent variation & -84.5 & -30.9 & 21.3 \\
\hline
\end{tabular}

Source: Ministry of Finance and Economic Development

119. The variations (Table 16) to budget support loans are largely due to the financial crisis and the government's response to it. In 2007-08, loans were distributed largely as estimated in the budget. However, when the financial crisis emerged, after the 2008-09 budget was approved, Mauritius sought, and was provided with an expansion of the World Bank's budget support loan from USD30 million to USD100 million, resulting in a large increase in borrowing relative to budget. These borrowing facilities were carried over into 2009, but in the event were not required or drawn-down, resulting in a large underspend. However, this was due to lack of demand on the Government of Mauritius' part, rather than any unwillingness to lend on the part of donors. 
Table 16. Direct Budget Support Loans: Actual versus Estimates

\begin{tabular}{lrrr}
\hline & $\begin{array}{r}\text { 2007-08 } \\
\text { MUR mln }\end{array}$ & $\begin{array}{r}\text { 2008-09 } \\
\text { MUR mln }\end{array}$ & $\begin{array}{r}\text { July-Dec 2009 } \\
\text { MUR mln }\end{array}$ \\
\hline Budgeted & 2,220 & 2,088 & 4,581 \\
Actual & 2,380 & 4,766 & 0 \\
Difference & 160 & 2678 & $-4,581$ \\
Percent variation & 7.2 & 128.3 & -100.0 \\
\hline
\end{tabular}

Source: Ministry of Finance and Economic Development

120. Budget support is provided on an annual or multi-annual basis. Given the large variations in disbursement timing, a $\mathrm{D}$ has been scored, but for the reasons outlined above, this does not imply a substantive problem with the timing of donor disbursements.

\section{D-2. Financial information provided by donors for budgeting and reporting on project and program aid}

This indicator has two dimensions which assess the: (i) completeness and timeliness of budget estimates by donors for project support; and (ii) frequency and coverage of reporting by donors on actual flows for project support.

\begin{tabular}{|c|c|c|c|c|}
\hline Dimensions to be assessed (scoring method M1) & \multicolumn{2}{|c|}{$\begin{array}{l}2010 \\
\text { Score }\end{array}$} & \multicolumn{2}{|c|}{$\begin{array}{l}2007 \\
\text { Score }\end{array}$} \\
\hline $\begin{array}{l}\text { (i) Donors provide budget estimates for disbursement of project aid } \\
\text { at stages consistent with the government's budget calendar and with } \\
\text { a breakdown consistent with the government budget classification }\end{array}$ & $\mathrm{A}$ & A & A & A \\
\hline $\begin{array}{l}\text { (ii) Donors provide regular reports at least quarterly on } \\
\text { disbursements for at least } 85 \text { percent of externally financed projects }\end{array}$ & $\mathrm{A}$ & & $\mathrm{A}$ & \\
\hline
\end{tabular}

\section{In FY2009, with the exception of a few project loans and grants from Asian} Development Bank (ADB), International Fund for Agricultural Development (IFAD), and China the majority of aid was funnelled to the budget as direct budget support. Project disbursements amounted to are very limited in Mauritius as most of the aid takes the form of budget support. For FY2009 budget estimates and disbursement reports were provided in a manner consistent with governments' budget calendar and classification requirements. Regular quarterly donor reports on disbursements are made for all projects.

\section{D-3. Proportion of aid that is managed by use of national procedures}

This indicator measures the proportion of aid managed by national procedures. 


\begin{tabular}{|l|c|c|}
\hline Dimension to be assessed (Scoring method M1) & $\begin{array}{c}\mathbf{2 0 1 0} \\
\text { Score }\end{array}$ & $\begin{array}{c}\mathbf{2 0 0 7} \\
\text { Score }\end{array}$ \\
\hline $\begin{array}{l}\text { (i) Overall proportion of aid funds to central government that are } \\
\text { managed through national procedures }\end{array}$ & B & None \\
\hline
\end{tabular}

122. The proportion of non-budget support aid, as indicated under indicator D2, relative to overall aid is small. This non-budget support assistance primarily comes from EU, India and China and is not managed through government procedures. Table 17 below shows the proportion of aid managed using national procedures in 2009 as just fewer than 90 percent, this indicator is therefore rated a $\mathrm{B}$.

Table 17. Aid Managed through National Procedures (Percent of total)

\begin{tabular}{lrrr}
\hline Type of Aid & $\begin{array}{r}\text { FY2007/08 } \\
\text { Actual } \\
\text { MUR mIn }\end{array}$ & $\begin{array}{r}\text { FY2008/09 } \\
\text { Actual } \\
\text { MUR mIn }\end{array}$ & $\begin{array}{r}\text { FY2009 } \\
\text { Actual } \\
\text { MUR mIn }\end{array}$ \\
\hline Foreign grants & & & \\
Direct budget support & 454 & 2,781 & 3,182 \\
Projects & 0 & 0 & 0 \\
Foreign loans & & & \\
$\quad$ Direct budget support & 2,380 & 4,766 & 0 \\
Projects & 305 & 1284 & 525 \\
Total & 3,139 & 8,831 & 3,707 \\
Aid managed by donor & 305 & 1,284 & 525 \\
Percent of total aid & 9.72 & 14.54 & 14.16 \\
\hline
\end{tabular}

Source: Ministry of Finance and Economic Development

\section{GOVERnMent ReForm Process}

123. An important focus of recent PFM reform efforts in Mauritius has been the strengthening of the budget formulation and management framework. This reform focus is in line with the results of the 2007 PEFA assessment which identified budget formulation as one of the key weaknesses in the PFM framework. The last three years has seen substantial progress being made in establishing the foundation of a more performance oriented program-based budgeting within a strengthened macro-fiscal framework. As can be seen from the 2010 assessment the ratings in the three areas related to budget credibility, comprehensiveness and transparency and policy-based budgeting show continued improvement.

124. There has been some concern that, although the support of core policy makers for reform has been relatively strong, the socio-economic context does fully support reform and some aspects of the complementary organizational reform are not making sufficient progress. Based on this analysis a number of proposals have been made for review 
of the linkages between performance-based budgeting and performance management and for strengthening of the accountability of management, these have yet to be fully implemented.

125. There has also been considerable work undertaken on strengthening budget execution processes. This includes a new legislative and institutional framework for procurement and debt management and strengthened budget execution arrangements. These reforms have also been under implementation during the period of the assessment and their impact is reflected in increased ratings for a number of indicators. In addition, many other PFM indicators related to accounting and financial reporting have maintained the high 2007 performance ratings in 2010.

126. External audit reform has included the adoption of modern auditing standards and methodologies and continued capacity development. These have assisted the NAO to maintain the high performance ratings given in the 2007 PEFA report in 2010. 


\section{Annex 1. Stakeholders Met}

\begin{tabular}{|c|c|c|}
\hline Name & Position & Institution \\
\hline Mr. A. Mansoor & Financial Secretary & MoFED \\
\hline Mr. P. Yip Wang Wing & Director, Economic and Finance & MoFED \\
\hline Mr. V. Bassant & Director, Economic and Finance & MoFED \\
\hline Mr. A. Ponnusawmy & Assistant Director & MoFED \\
\hline Mr. M. Bheekhee & Lead Analyst & MoFED \\
\hline Mrs. D. Lan Hing Po & Lead Analyst & MoFED \\
\hline Mr. A. Acharuz & Senior Analyst & MoFED \\
\hline Mrs. S. Appanah & Senior Analyst & MoFED \\
\hline Mrs. U. Beegun-Ramduny & Senior Analyst & MoFED \\
\hline Mr. D. Baichoo & Senior Analyst & MoFED \\
\hline Mr. S. Suhootoorah & Senior Analyst & MoFED \\
\hline Mr. K. Guptar & Advisor & MoFED \\
\hline Mr. I. Beejah & Director, Internal Control & MoFED \\
\hline Mr. H. Ghamy & Manager, Internal Control & MoFED \\
\hline Mr. J. Ramyed & Analyst & MoFED \\
\hline Mr. N. Codadeen & Analyst & MoFED \\
\hline Mr. P. Buchoo & Analyst & MoFED \\
\hline Ms. R. Goolamamode & Analyst & MoFED \\
\hline Mr. G. Gopee & Director, MAB & Prime Minister's Office \\
\hline Mr. A. Mudhoo & Deputy Director & Procurement Policy Office \\
\hline Mr. J. Valaythen & Accountant General & The Treasury \\
\hline Mr. C. Romooah & Deputy Accountant General & The Treasury \\
\hline Mr. S. Ramdeen & Assistant Accountant General & The Treasury \\
\hline Mr. S. Annauth & Assistant Accountant General & The Treasury \\
\hline Mr. N. Rambajun & Accountant & The Treasury \\
\hline Ms. S. Jugoo & Accountant & The Treasury \\
\hline Ms. L.F. Cheung Kai Suet & Director of Statistics & Central Statistics Office \\
\hline Mrs. R.Appadu & Principal Statistician & Central Statistics Office \\
\hline Mr. E. Wong Ping Lun & Statistician & Central Statistics Office \\
\hline Mrs. S. Geemul & Senior Statistical Officer & Central Statistics Office \\
\hline Mr. R. Jugarnath & Director of Audit & National Audit Office \\
\hline Mrs. P. Tse Yuet Cheong & Deputy Director & National Audit Office \\
\hline Mr. P.K Napaul & Deputy Director & National Audit Office \\
\hline Mr. Doorgakant & Chief Examiner & National Audit Office \\
\hline Mr. F. Lotun & Manager, Financial Operations & $\begin{array}{l}\text { Ministry of Local } \\
\text { Government and Outer } \\
\text { Islands (MOLG) }\end{array}$ \\
\hline Mr. A. Rujub & Acting Assistant Manager, F.O & MOLG \\
\hline Mrs. G. Toory & $\begin{array}{l}\text { Senior Financial Operations } \\
\text { Officer (SFOO) }\end{array}$ & Police Department \\
\hline Mr. V. A Kallee & Assistant Manager, F.O & $\begin{array}{l}\text { Minstry of Public } \\
\text { Infrastructure, NDU \& LTS } \\
\text { (MPI) }\end{array}$ \\
\hline
\end{tabular}




\begin{tabular}{|c|c|c|}
\hline Name & Position & Institution \\
\hline Ms. F. Pauline & SFOO & MPI \\
\hline Mr. J. K. Kasary & SFOO & MPI \\
\hline Mr. M. Bhenick & Assistant Manager, F.O & MPI \\
\hline Mr. B. Purusram & Assistant Manager, F.O & $\begin{array}{l}\text { Min of Agro-Industry \& Food } \\
\text { Security }\end{array}$ \\
\hline Mr. C. Singelee & Manager, F.O & Min of Education and HR \\
\hline Mrs. A. Suddoo & Assistant Manager, F.O & $\begin{array}{l}\text { Min of Health and Quality of } \\
\text { Life }\end{array}$ \\
\hline Mr. A. Cheerkoot & Deputy Manager & $\begin{array}{l}\text { Central Informatics System } \\
\text { Division(CISD) }\end{array}$ \\
\hline Mrs. O. Joggesser & System Analyst & CISD \\
\hline Mrs. S. Bissoonauth & $\begin{array}{l}\text { Assistant Financial Operations } \\
\text { Officer }\end{array}$ & CISD \\
\hline Mrs. S. Lotun & Deputy Clerk & National Assembly \\
\hline Ms. U. Ramchurn & Clerk Assistant & National Assembly \\
\hline Mr. S. Lal & Director General & $\begin{array}{l}\text { Mauritius Revenue Authority } \\
\text { (MRA) }\end{array}$ \\
\hline Dr. P. Seth & $\begin{array}{l}\text { Director, Research Policy \& } \\
\text { Planning }\end{array}$ & MRA \\
\hline Mr. N. Bisessur & $\begin{array}{l}\text { Assistant Director, Research, } \\
\text { Policy \& Planning }\end{array}$ & MRA \\
\hline Mr. P. Ramkissoon & $\begin{array}{l}\text { section head, Large Taxpayer } \\
\text { Department }\end{array}$ & MRA \\
\hline Mr. Rajanah & $\begin{array}{l}\text { section head, Large Taxpayer } \\
\text { Department }\end{array}$ & MRA \\
\hline Mr. M. Hannelas & $\begin{array}{l}\text { Director, Small \& Medium Tax } \\
\text { Payers }\end{array}$ & MRA \\
\hline Mr. D. Ramdin & Director, Operational Services & MRA \\
\hline Mrs. Conhyedass & Section head Debt Management & MRA \\
\hline Mr. T. Moorghen & $\begin{array}{l}\text { Acting Director, Tax Education } \\
\text { and Communication }\end{array}$ & MRA \\
\hline Ms. C. Gunnoo & Director Fiscal investigations & MRA \\
\hline Mrs. S.D. Mooroogen & Director Internal Audit & MRA \\
\hline Mr. S. Nadan & Team Leader, Internal Audit & MRA \\
\hline Mr. V. Ramdonee & Legal Advisor & MRA \\
\hline Mr. N. Moonusawny & Director Financial Administration & MRA \\
\hline Ms. I. Reetun & Assistant Director of Finance & MRA \\
\hline Mr. G. Kelly & Team Leader & MRA \\
\hline Mr. R. Oree & Team Leader & MRA \\
\hline Mr. H. Jankee & Chief Economist & Bank of Mauritius \\
\hline Mr. J. Pandoo & $\begin{array}{l}\text { Head, Financial Markets } \\
\text { Operations Division }\end{array}$ & Bank of Mauritius \\
\hline Mrs. M. Heerah Pampusa & $\begin{array}{l}\text { Head, Financial Markets Analysis } \\
\text { Division }\end{array}$ & Bank of Mauritius \\
\hline Mr. S.Gopaul & Chief (Accounting \& Budgeting & Bank of Mauritius \\
\hline
\end{tabular}




\begin{tabular}{|c|c|c|}
\hline Name & Position & Institution \\
\hline Mr. J. K. Ramtohul & $\begin{array}{l}\text { Division) } \\
\text { Head Accounting Budgeting } \\
\text { Division }\end{array}$ & Bank of Mauritius \\
\hline Mr. A. Bonieux & Partner & Price Waterhouse Coopers \\
\hline Mr. A. Sandrazie & President & $\begin{array}{l}\text { Mauritius Tax Payers } \\
\text { Association }\end{array}$ \\
\hline Mr. Rungasamy & Vice-President & $\begin{array}{l}\text { Mauritius Tax Payers } \\
\text { Association }\end{array}$ \\
\hline $\begin{array}{l}\text { Mr. M. Irshad Cassam } \\
\text { Laulloo }\end{array}$ & Chairman & $\begin{array}{l}\text { Assessment Review } \\
\text { Committee }\end{array}$ \\
\hline Mr. R. Nookadee & Secretary & $\begin{array}{l}\text { Mauritius Council of Social } \\
\text { Services (MACOSS) }\end{array}$ \\
\hline Ms. P. Nagessur & $\begin{array}{l}\text { Administrative and Finance } \\
\text { Officer }\end{array}$ & MACOSS \\
\hline Mr. A. Schaffert & Head of EU Delegation & EU \\
\hline Mrs. L. Nosib & Chargé de Projets & EU \\
\hline Ms. T. Živko & Project Officer & EU \\
\hline Mr. Y. Hookoomsing & Co-ordination Analyst & $\begin{array}{l}\text { Office of UN Resident } \\
\text { Coordinator }\end{array}$ \\
\hline Mr. A. Patten & Chargé de Projets & AFD \\
\hline Ms. S. Chaleon & Project Officer & AFD \\
\hline Ms. A. Shall & Consultant & UNDP \\
\hline
\end{tabular}




\section{Annex II. Background Documents and Previous Analytical Work References}

1. Annual Report of the Treasury 2007/8, 2008/9 and December 2009

2. Director of Audit Report 2007/8 and December 2009

3. Budget Estimates (detailed) 2007, 2008, 2009, 2010, 2011

4. Treasury Warrants file

5. Supplementary budget passed by parliament during the course of the year

6. Annual Report of the Bank of Mauritius for the Year ended 30 June 2009

7. Digest of Public Finance Statistics 2008, 2009.

8. National Audit Office Activity Reports 2007/08, 2008/09

9. Report of the Director of Audit year period 31st December 2009

10. NAO Report Implementation of Program Budgeting 2008/09

11. Report of the Public Accounts Committee March 2008.

12. Standing Orders of The National Assembly, 1995

13. NAO Performance Audit Reports 1,2 3

14. Final accounts of the Road Authority 2008, 2009

15. Public Debt Management Act 2008.

16. The Finance and Audit Act

17. Financial Management Manual

18. Audit Charter

19. Copies of Bank reconciliations

20. General ledger examples

21. http://www.gov.mu/portal/site/treasurysite

22. http://www.gov.mu/portal/site/MOFSite

23. Mauritius IMF FAD TA Reports 2008, 2009,2010

24. PEFA Manual and related materials 
Annex III. Detailed Tables and Calculations

Table A1. Material Special Fund Movements in the Assessment Period 2007-08 to 2009

\begin{tabular}{|c|c|c|c|c|}
\hline Movements in Special Funds & 2007-08 & 2008-09 & July-Dec 2009 & Total \\
\hline Receipts & 3,120 & 5,692 & 2,650 & 11,462 \\
\hline Maurice lle Durable Fund & 1,000 & 0 & 200 & 1,200 \\
\hline $\begin{array}{l}\text { Human Resources, Knowledge \& Arts } \\
\text { Development Fund }\end{array}$ & 1,000 & 0 & 0 & 1,000 \\
\hline Food Security Fund & 1,000 & 0 & 0 & 1,000 \\
\hline Local Infrastructure Fund & 120 & 375 & 700 & 1,195 \\
\hline Social Housing Infrastructure Fund & 0 & 1,167 & 0 & 1,167 \\
\hline Business Growth Fund & 0 & 3,150 & 0 & 3,150 \\
\hline Road Decongestion Program Fund & 0 & 1,000 & 1,750 & 2,750 \\
\hline Payments & 0 & 747 & 718 & 1,465 \\
\hline Maurice Ile Durable Fund & 0 & 103 & 105 & 208 \\
\hline $\begin{array}{l}\text { Human Resources, Knowledge \& Arts } \\
\text { Development Fund }\end{array}$ & & 42 & 61 & 103 \\
\hline Food Security Fund & 0 & 9 & 55 & 64 \\
\hline Local Infrastructure Fund & 0 & 0 & 154 & 154 \\
\hline Social Housing Infrastructure Fund & 0 & 381 & 99 & 480 \\
\hline Business Growth Fund & 0 & 212 & 243 & 455 \\
\hline Road Decongestion Program Fund & 0 & 0 & 1 & 1 \\
\hline Net Expenditure from Funds & $-3,120$ & $-4,945$ & $-1,932$ & $-9,997$ \\
\hline Interest and Other Income & 0 & 225 & 220 & 445 \\
\hline \multicolumn{5}{|l|}{ Other Sources } \\
\hline Non-Government FSD Receipts & & 1,696 & & 1,696 \\
\hline Non-Government FSD Payments & & $-1,696$ & -850 & $-2,546$ \\
\hline Total Fund Receipts & 3,120 & 7,613 & 2,970 & 13,703 \\
\hline Total Fund Payments & 0 & 2,443 & 1,668 & 4,111 \\
\hline Remaining Balance in Funds & 3,120 & 5,170 & 1,302 & 9,592 \\
\hline
\end{tabular}


Table A2 (i). Taxpayer Cases

\begin{tabular}{|c|c|c|c|c|c|c|c|c|}
\hline & \multicolumn{2}{|c|}{ CIT } & \multicolumn{2}{|c|}{ VAT } & \multicolumn{2}{|c|}{ PIT } & \multicolumn{2}{|c|}{ Total } \\
\hline & No. & Amount & No. & Amount & No. & Amount & No. & Amount \\
\hline 2007-08 & & & & & & & & \\
\hline $\begin{array}{l}\text { Cases at the start of the } \\
\text { year }\end{array}$ & 12 & 209.4 & 85 & 208.4 & 196 & 416.9 & 293 & 834.7 \\
\hline Cases lodged & 28 & 247.7 & 70 & 145.8 & 102 & 114.6 & 200 & 508.1 \\
\hline Cases struck out & & & 1 & 0.2 & & & 1 & 0.2 \\
\hline $\begin{array}{l}\text { Cases withdrawn, } \\
\text { agreed, allowed }\end{array}$ & & & 12 & 5.6 & 1 & 0.27 & 13 & 5.87 \\
\hline Cases determined & 10 & 7.3 & 48 & 68.5 & 116 & 150.8 & 174 & 226.6 \\
\hline $\begin{array}{l}\text { Cases at the end of the } \\
\text { year } \\
\text { 2008-09 }\end{array}$ & 30 & 449.9 & 94 & 207.9 & 181 & 380.4 & 305 & $1,038.2$ \\
\hline $\begin{array}{l}\text { Cases at the start of the } \\
\text { year }\end{array}$ & 30 & 449.9 & 94 & 208.0 & 181 & 380.4 & 305 & $1,038.2$ \\
\hline Cases lodged & 51 & 325.0 & 97 & 225.6 & 269 & 418.0 & 417 & 968.5 \\
\hline Cases struck out & & & 6 & 2.7 & & & 6 & 2.7 \\
\hline $\begin{array}{l}\text { Cases withdrawn, } \\
\text { agreed, allowed }\end{array}$ & 1 & 1.7 & 6 & 7.4 & & & 7 & 9.1 \\
\hline Cases determined & 10 & 71.3 & 44 & 18.7 & 102 & 80.1 & 156 & 170.1 \\
\hline $\begin{array}{l}\text { Cases at the end of the } \\
\text { year }\end{array}$ & 70 & 574.8 & 135 & 348.5 & 348 & 641.8 & 553 & $1,565.1$ \\
\hline
\end{tabular}

Source: ARC, published and unpublished reports 2007-09

Table A2 (ii). Taxpayer Cases

\begin{tabular}{|c|c|c|c|c|c|c|}
\hline & LTD & VAT & $\begin{array}{r}\text { Income } \\
\text { Tax }\end{array}$ & Customs & $\begin{array}{c}\text { Total involvi } \\
\text { MRA }\end{array}$ & $\begin{array}{r}\text { Registrar- } \\
\text { General }\end{array}$ \\
\hline \multicolumn{7}{|l|}{ Second half of 2009} \\
\hline $\begin{array}{l}\text { Cases at the start of the } \\
\text { half year }\end{array}$ & 75 & 138 & 387 & 236 & 836 & 3,122 \\
\hline Cases lodged & 57 & 49 & 139 & 89 & 334 & 83 \\
\hline Cases struck out & 2 & 10 & 16 & 4 & 32 & 75 \\
\hline $\begin{array}{l}\text { Cases withdrawn, } \\
\text { agreed, allowed }\end{array}$ & 0 & 11 & 10 & 4 & 25 & 58 \\
\hline Cases determined & 21 & 21 & 56 & 8 & 106 & 760 \\
\hline $\begin{array}{l}\text { Cases at the end of the } \\
\text { half year }\end{array}$ & 109 & 145 & 444 & 309 & 1,007 & 2,312 \\
\hline
\end{tabular}

Source: ARC, published and unpublished reports 2007-09 
Table A3. Comparison between Actual and Central Budgetary Government Primary Expenditure (MUR millions)

\begin{tabular}{lrrr}
\hline & $\mathbf{2 0 0 7 - 0 8}$ & $\mathbf{2 0 0 8 - 0 9}$ & July - Dec \\
\hline Budget (Original) & 47,774 & 59,721 & 33,949 \\
Actual & 49,454 & 59,962 & 33,716 \\
Difference & 1,680 & 241 & -233 \\
Percent difference & 3.5 & 0.4 & -0.7 \\
\hline
\end{tabular}

Source: Ministry of Finance and Economic Development

Table A4 (i). Taxpayer Audits

\begin{tabular}{|l|rr|rr|}
\hline \multirow{2}{*}{ Cases selected for audit by the LTD } & \multicolumn{2}{|c|}{$\mathbf{2 0 0 7 - 0 8}$} & \multicolumn{2}{c|}{$\mathbf{2 0 0 8 - 0 9}$} \\
Target & $\begin{array}{r}\text { Actual } \\
\text { (percent) }\end{array}$ & $\begin{array}{r}\text { Target } \\
\text { (percent) }\end{array}$ & $\begin{array}{r}\text { Actual } \\
\text { (percent) }\end{array}$ \\
\hline Income Tax & 2.5 & 0.19 & 2.8 & 1.8 \\
VAT & 10 & 3.3 & 13 & 4.1 \\
PAYE & 10 & 0.5 & 0 & 2.0 \\
Gaming & 20 & 18.0 & 22 & 69 \\
Horse Racing & 100 & 0.0 & 100 & 100 \\
All cases & 25 & 11.1 & 25 & 29.2 \\
\hline
\end{tabular}

Sources: MRA Annual Report 2007-08 page 105 and MRA Annual Report 2008-09, page 105

Table A4 (ii). Taxpayer Audits

\begin{tabular}{lrrr}
\hline Audit performance & $\mathbf{2 0 0 6 - 0 7}$ & $\mathbf{2 0 0 7 - 0 8}$ & $\mathbf{2 0 0 8 - 0 9}$ \\
\hline Number of audits & 1,102 & 2,420 & 3,503 \\
Of which office & 685 & 1,667 & 2,349 \\
Of which on site & 417 & 753 & 1,154 \\
Number of amended assessments & 3,178 & 4,599 & 2,608 \\
Of which Individuals [PIT] & 2,645 & 3,306 & 1,588 \\
Of which Companies [CIT] & 351 & 879 & 715 \\
Of which VAT & 182 & 414 & 305 \\
Amount of additional assessments (mIn. MUR.) & 963.7 & $2,105.7$ & $1,862.4$ \\
Of which Individuals & 195.0 & 450.1 & 342.9 \\
Of which Companies & 580.6 & 754.9 & 997.6 \\
Of which VAT & 188.1 & 900.7 & 521.9 \\
Average amount per assessment & 0.303 & 0.458 & 0.714 \\
Individuals & 0.074 & 0.136 & 0.216 \\
Companies & 1.654 & 0.859 & 1.395 \\
VAT & 1.034 & 2.176 & 1.711 \\
\hline
\end{tabular}

Source: MRA Annual Reports 2006/07 page 32, 2007/08 page 47 and 2008/09, page 39 
Table A5. Taxpayer Debt

\begin{tabular}{|c|c|c|c|c|c|c|}
\hline $\begin{array}{l}\text { Taxpayer Debt } \\
\text { (millions of MUR) }\end{array}$ & $\begin{array}{r}(1) \\
\text { Total } \\
\text { debts, } \\
\text { beginning } \\
\text { of year }\end{array}$ & $\begin{array}{r}\text { (2) } \\
\text { Non- } \\
\text { collectible } \\
\text { debt, } \\
\text { beginning } \\
\text { of year }\end{array}$ & $\begin{array}{r}(3) \\
\text { Collectible } \\
\text { debt, } \\
\text { beginning } \\
\text { of year }\end{array}$ & $\begin{array}{c}(4) \\
\text { Additions } \\
\text { to debt } \\
\text { during } \\
\text { the year }\end{array}$ & $\begin{array}{c}(5) \\
\text { Collections } \\
\text { during the } \\
\text { year }\end{array}$ & $\begin{array}{c}\text { (6) } \\
\text { Collectible } \\
\text { debt, end } \\
\text { of year }\end{array}$ \\
\hline \multicolumn{7}{|l|}{$2007 / 08$} \\
\hline (Personal) Income Tax & 713.6 & 307.8 & 405.8 & 420.3 & 308.4 & 517.7 \\
\hline Corporate (Income) Tax & 739.7 & 304.8 & 434.9 & 586.2 & 446.0 & 575.1 \\
\hline VAT & 721.0 & 255.7 & 465.3 & 917.2 & 411.0 & 971.5 \\
\hline Gambling \& Others & 283.0 & 146.4 & 136.7 & 44.3 & 35.6 & 145.4 \\
\hline Total & $2,457.3$ & $1,014.7$ & $1,442.7$ & $1,968.0$ & $1,201.0$ & $2,209.7$ \\
\hline As a percentage of (3) & & & & & 83.2 & \\
\hline \multicolumn{7}{|l|}{$2008 / 09$} \\
\hline (Personal) Income Tax & 809.2 & 291.5 & 517.7 & 159.2 & 230.7 & 446.2 \\
\hline Corporate (Income) Tax & $1,525.9$ & 950.9 & 575.1 & 357.8 & 340.5 & 592.4 \\
\hline VAT & $1,563.3$ & 591.9 & 971.5 & 276.4 & 471.1 & 776.8 \\
\hline Gambling \& Others & 277.6 & 132.1 & 145.4 & 3.2 & 36.1 & 112.5 \\
\hline Total & $4,176.0$ & $1,966.4$ & $2,209.7$ & 796.6 & $1,078.4$ & $1,927.9$ \\
\hline As a percentage of (3) & & & & & 48.8 & \\
\hline
\end{tabular}

Column (1) = Column (2) + Column (3); Column (6) = Column (3) + Column (4) - Column (5)

Column (5) includes the collection of debts that arose after the beginning of the year.

Source: MRA Annual reports 